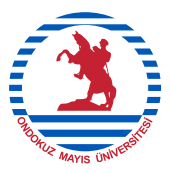

Ondokuz Mayıs Üniversitesi İnsan Bilimleri Dergisi,

Ondokuz Mayıs University Journal of Humanities

e-ISSN: 2717-8072, İBD, December 2021, 2(2): 97-128

\title{
Bir Köy Okulunun Serencamı: Bafra-Tekkesarmaşık ilkokulu
}

\author{
The Fate of a Village School: \\ Bafra-Tekkesarmaşık Primary School
}

Prof. Dr. Zafer GÖLEN

1 Burdur Mehmet Akif Ersoy Üniversitesi Fen-Edebiyat Fakültesi

•zgolen@mehmetakif.edu.tr • ORCID > 0000-0003-3162-6076

Makale Bilgisi / Article Information

Makale Türü / Article Types: Araştırma Makalesi / Research Article

Geliş Tarihi / Received: 25 Ekim / October 2021

Kabul Tarihi / Accepted: 7 Kasım / November 2021

Yıl/Year: 2021 | Cilt -Volume: 2 | Sayı-Issue: 2 | Sayfa/Pages: 97-128

Atıf/Cite as: Gölen, Z., "Bir Köy Okulunun Serencamı: Bafra-Tekkesarmaşık Ilkokulu - The Fate of a Village School: Bafra-Tekke Sarmaşik Primary School", Ondokuz Mayıs Üniversitesi Insan Bilimleri Dergisi - Ondokuz Mayıs University Journal of Humanities, 2 (2), Aralık 2021: 97-128.

https://10.51533/insanbilimleri.1014687 


\section{BIR KÖY OKULUNUN SERENCAMI: BAFRA-TEKKESARMAŞIK ILKOKULU}

\section{THE FATE OF A VILLAGE SCHOOL: BAFRA-TEKKESARMAŞIK PRIMARY SCHOOL}

Neşe Alten, Aybüke Yalçın ve Necmettin Yılmaz şahsinda tüm şehit öğretmenlerimize ithaf olunur.

Öz:

Türkiye Cumhuriyeti'nin kurulmasıyla birlikte ülke sathında topyekûn eğitim seferberliği başlatıldı. Ancak ülkenin içinde bulunduğu iktisadî darlık ve II. Dünya Savaşı'nın ortaya çıkardığı olumsuz şartlar yüzünden Samsun'un Bafra ilçesine sadece $10 \mathrm{~km}$ uzakta bulunan Tekkesarmaşık Köyü’ne ilkokul, Cumhuriyet'in ilanından 27 yıl sonra gelebildi. Okul denilen bina küçük bir lojman ve tek sınıftan ibaret bir yapı idi. Orta altı gelir düzeyine sahip, tamamı çiftçilikle geçinen köy sakinleri okulu sahiplendiler. Kız ve erkek çocuklarını ayırt etmeksizin derhal okula yolladılar. Ne var ki köylülerin eğitimden beklentileri farklı idi. Çoğu çocuk okula sadece okuma yazma ve dört işlem yapacak kadar matematik öğrenmesi için gönderildi. 1960'ların ortalarına kadar birçok çocuk mezun dahi olamadan okuldan ayrilmak zorunda kaldı. Yine de okul eğitime devam ettiği 56 yıl boyunca köyün adeta kalbi işlevini gördü. Köyün hem akademik hem de en önemli sosyal mekânı haline geldi. 1965-1990 yılları okulun altın dönemleriydi. Özellikle öğrenci sayısı bakımından okulun en kalabalık dönemi bu yıllardı. Ardından köy nüfusundaki azalma ile birlikte okul ve öğretmen sayısı da düştü. Niha- yet 2006 'da taşımalı sisteme geçilmesi ile okul kaderine terkedildi. Bu çalışmada okuldan arta kalan belgelere dayalı olarak okulun tarihi ortaya konulmaya çalışıldı. Çalışmanı tek amacı eğitim tarihine katkı değil, aynı zamanda köylerin hafızası niteliğinde olan ve kaderine terkedilen bu okulların arşivlerine, mümkünse de binaların korunmasının önemine dikkat çekmektir.

Anahtar Kelimeler: Tekkesarmaşık Köyü İlkokulu, Bafra, Köy Öğretmeni, Okul Arşivi.

\section{ABSTRACT:}

With the establishment of the Republic of Turkey, in the entire country, a full-scale education campaign was launched. However, due to the economic constriction of the country and the unfavourable conditions caused by the World War II, the primary school could be opened in Tekkesarmaşık Village, which is only $10 \mathrm{~km}$ away from the Bafra district of Samsun, 27 years after the proclamation of the Republic. The so-called school building consisted of a small lodging and a single classroom building. Village residents with a lower-middle income level, all of whom lived on farming, embraced the school. 
They immediately sent boys and girls to school, indiscriminately. However, the expectations of the villagers from education were different. Most children were sent to school to learn just reading and writing and math enough to do four operations. Many children had to leave school before they could even graduate. Still, the school functioned as the heart of the village during its 56 years of education. It became both the academic and the most important social venue of the village. The years 1965-1990 were golden times for the school. It was the most crowded period especially in terms of the number of students. Then, with the decrease in the village population, the number of schools and teac- hers also decreased. Finally, by the transition to the mobile teaching in 2006, it was left to its fate. In this study, the history of the school is revealed based on the documents about the school. The sole purpose of his work is not only to contribute to the history of education, but also to draw attention to the archives of these schools, abandoned to their fate and are regarded as the memory of the villages and to attract notice to the importance of preserving the buildings, if possible.

Keywords: Tekkesarmaşık Village Primary School, Bafra, Village Teacher, School Archive.

\section{释粰 \\ GíRiş}

Savaşlarla yıpranmış, yok olmanın eşiğine gelmiş millet, en olmazı başarmış, tüm emperyalist güçlere karşı ölüm kalım savaşı vermiş ve 1923 'te Cumhuriyet'i kurmayı başarmıştır. Cumhuriyetle birlikte topyekûn bir kalkınma hamlesi başlatan Mustafa Kemal Atatürk, sanayi ve iktisadi kalkınmanın yanında en önemli yatırımın insan olduğunu biliyordu. Bu yüzden köy okulları Cumhuriyet'in en önemli insana yatırım projesi oldu. Ancak çok önemli yol kat edilse de iktisadî sorunlar yüzünden istenilen hedefe ulaşılamadı. Eğitim Bakanı Saffet Arıkanın May1s 1936'da TBMM'de söylediğine göre, kırk bin köyün otuz beş bininde hâlâ okul ve öğretmen yoktu. Okul olan köylerde de eğitim süresi üç yıldı. ${ }^{[1]}$ Tüm olumsuzluklara rağmen Cumhuriyet idaresi köy okul projesinden vazgeçmedi. 1960'lara gelindiğinde köy okulları ülke sathına dağılmış durumdaydı.

Köy okulları sadece bir eğitim kurumu olarak görülmemelidir. Okullar aynı zamanda köy, mahalle ya da şehir hafızasının tutulduğu çok önemli birimlerdir. Fakat 1989-90 eğitim öğretim yılında iki ilde başlayan taşımalı eğitim sistemi zamanla tüm illeri kapsar hale geldi. Böylece köy okulları birer birer kapanmaya başladı. Günümüzde yaklaşık 20.000 köy okulu kapalı durumdadır. Okulların kapanması ile birlikte bir kısmı neredeyse Cumhuriyetle yaşıt bu okullarda ilkel de olsa

1 Yahya Akyüz, Türk Eğitim Tarihi, Pegem Akademi, Ankara 2010, s. 346. 
tutulan arşivler kaderine terk edildi. Hâlbuki binlerce okulda üretilen milyonlarca belge doğru bir tasniften sonra Türkiye yerel tarihi için paha biçilmez bir kaynak olabilirdi. Fakat bu yapılmadı, çoğu ilkokulda artık önemi kalmadığına inanılan belgeler fare ve nemin insafına bırakıldı. Böylece Cumhuriyetin yüz yıllık yerel birikimi maalesef ya yok oldu ya da yok olmak üzeredir. Bu makalenin hedeflerinden biri de bu üzücü duruma dikkat çekmektir.

Yerel Tarih çalışmalarında en büyük problem kaynaklara ulaşmadaki güçlüktür. Yerelde elde edemediğiniz hiçbir kaynağa ulaşma şansınız yoktur. Zira klasik arşivlere girecek kadar önemli bir hadise yoksa üretilen birçok belge geri dönüşüm için SEKA'ya gönderilmiştir. ${ }^{[2]} \mathrm{Bu}$ tür çalışmalardaki bir başka sorun da ilgili birimlerin arşivleri araştırmacılara açık olmadığından herhangi bir belgeye ulaşmak nerdeyse imkânsızdır. ${ }^{[3]}$

Tekkesarmaşık, Bafra’ya 10 km uzaklıkta bir köy olup idarî örgütlenmesi Cumhuriyet öncesine dayanan bir yerleşim yeridir. Okul açıldığında Merkez, Sarmaşık ve Benliuşağı Mahallelerinden oluşan orta büyüklükte bir köydür. Daha sonra Sarmaşık, Tekkesarmaşık'tan ayrılarak müstakil köy olmuştur. Köyün Batısında Sarmaşık, Gazibeyli ve Şeyhulaş, Güneyinde İkizpınar, Kuzeyinde Çatak (Lengerli), Doğusunda ise Sürmeli köyleri bulunmaktadır. ${ }^{[4]} 1935$ nüfus sayımına göre köyde 166 'sı erkek 175'i kadın olmak üzere 341 kişi yaşamaktayd1. ${ }^{[5]} 1980$ 'e gelindiğinde ise köy nüfusu 327'si erkek 332'si kadın olmak üzere 659'a yükselmiştir. ${ }^{[6]} 1985$ 'te sayı 352'si erkek 353'ü kadın olmak üzere 705'e ulaşmıştır. ${ }^{[7]}$ Fakat 1990'larla birlikte köy nüfus kaybetmeye başlamıştır. 1990'da köyde 340’1 erkek 336’sı kadın olmak üzere 676 kişi yaşamaktaydı. ${ }^{[8]} 1992$ 'de kurulan İkizpınar Beldesine bağlanan köyün sonraki yıllardaki nüfusu ayrıca belirtilmediğinden öğrenilememiştir. Köy,

2 Samsun Valiliği Milli Eğitim Gençlik ve Spor Müdürlüğü tarafından Bafra Kaymakamlığı illçe Eğitim Gençlik ve Spor Müdürlüğüne gönderilen 1.11.1984 tarih ve 850/42834 sayılı Adi evrak ve kırtasiye konulu yazl; Tekkesarmaşık Ilkokulu Müdürlüğü tarafından Illçe Eğitim Gençlik ve Spor Müdürlüğüne gönderilen 27.11.1984 tarih ve 830/30 sayılı Adi evrak ve kırtasiye konulu yazı. illgi yazıda istenen adi evrak ve kırtasiyenin bir torba halinde gönderildiği yazıdır. Bu imha harekâtı Milli Ekonominin zarar görmemesi adına yapılmıştır. Toplanan evraklar Milli ekonomi adına Taşköprü SEKA Sigara Kâğıt Fabrikası’na gönderilerek, yerine kullanılabilecek yazı kâğıdı alınmıştır.

3 Devlet Arşivleri Başkanlığı katalog tarama sisteminde basit ya da detaylı bir tarama için Tekkesarmaşık yazıldığında hiçbir kayıt gözükmemektedir. https://katalog.devletarsivleri.gov.tr/Sayfalar/Arama/OzelArama.aspx (Erişim tarihi: 7.11.2020)

$4 \quad$ Resim 8.

5 Türkiye Cumhuriyeti Başbakanlık İstatistik Genel Direktörlüğü, Genel Nüfus Sayımı Kat'îve Mufassal Neticeler Samsun Vilâyeti, Mehmet ihsan Basımevi, Ankara 1937, s. 9.

6 Genel Nüfus Sayımı Nüfusun Sosyal ve Ekonomik Nitelikleri 12.10.1980. Ili:55-Samsun, Başbakanlık Devlet İstatistik Enstitüsü, Ankara 1983, s. 7.

7 Genel Nüfus Sayımı Nüfusun Sosyal ve Ekonomik Nitelikleri 20.10.1985. Ili:55-Samsun, Başbakanlık Devlet İstatistik Enstitüsü, Ankara 1989, s. 7.

81990 Genel Nüfus Sayımı. Nüfusun Sosyal ve Ekonomik Nitelikleri 20.10.1985. ili:55-Samsun, TC. Başbakanlık Devlet Istatistik Enstitüsü, Ankara 1994, s. 28. 
2013 yılına kadar İkizpınar Beldesi’ne bağlı iken Büyükşehir Yasası gereğince belde statüsü lağvedilince Tekkesarmaşık da mahalle olarak tanımlanmıştır.

\section{A-Bina ve Bahçe}

Bafra köylerinde ilk ilkokullar 1928 yılında Doğankaya ve Sarıçevre köylerinde faaliyete geçmiştir. En son ise 1963'te Kuşluğan, Terzili ve Türbe köy ilkokulları açılarak Bafra’da okulsuz köy kalmamıştır. Bafra’ya bağlı 84 köyden 4'ünde ne zaman okul yapıldığ tespit edilememiştir. Kalan 80 köyden 33'ü 1950 öncesinde, 41’i ise 1951'den sonra eğitim öğretime başlamıştır. Tekkesarmasık İlkokulu 1950'de hizmete açılmıştır. ${ }^{[9]}$

Okul binası Samsun ili Bafra ilçesi Tekke köyü Memoğlu mevkiindedir. Gayrimenkulün niteliği "kâgir okul ve uygulama bahçesi" olarak belirtilmiştir. Okul arsası daha evvel 7 ayrı hisse iken 1948 yılında köy mülkiyetine geçmiştir. Okula ait ilk tapu kaydı Mayıs 1961'de yapılmış, ardından 10 Eylül 1968'de yeni bir tespit daha yapılmıştır. İlk tapu kayıtlarında okulun yüzölçümü $3.360 \mathrm{~m} 2$ olarak görünmektedir. 5 Eylül 2019'da yapılan yeni kadastro ölçümünde okul alanı $3.180 \mathrm{~m} 2$ olarak belirlenmiş ve köy mülkiyetinden alınarak Maliye Hazinesi’ne devredilmiştir. ${ }^{[10]}$

Tekkesarmasık İlkokulunda eğitim öğretime 10 Kasım 1950'de başlamıştır. Okulun bina inşaatı okulun açılmasına yetişmediğinden 1950-51 eğitim öğretim yılının güz döneminde eğitim Rahim Duman’a ait kahvehanede verilmiştir. ${ }^{[1]} \mathrm{Ba}$ har döneminde ise devlet tarafından yapılan mevcut okul binasına taşınılmıştır. Bina ilk açıldığında 1 derslik, 1 lojman, 1 müdür ve öğretmen odasından müteşekkildir. 1971-72 ve 1972-73 yıllarında Müdür Sadrettin Çiçek’in şahsî gayretleri ile iki derslik daha ilave edilmiştir.

Okul 1950'den, taşımalı sistem sebebiyle kapandığı yıl olan 2005-2006 eğitim öğretim yılına kadar aynı binada eğitim öğretim faaliyetine devam etmiştir. Bina lojman hariç 150 m2'dir. Okul girişine 6 basamaklı bir merdivenle ulaşılır. Girişte 3.30 x 5.40 ölçülerinde 17.82 m2'lik küçük bir koridor, solda öğretmen ve müdür odası olarak kullanılan 3.30 x 3.30 m ölçüsünde 10.89 m2'lik bir oda, girişte sağda daha sonra okula ilave edilen 4.70 x 7.30 m boyutlarında $34.31 \mathrm{~m} 2$ 'lik bir sinıf ve girişin karşısında ana bina projesi dâhilinde yapılmış olan 9 x 5.80 m boyutunda $52.2 \mathrm{~m} 2$ 'lik okulun en büyük sınıfı yer almaktadır. Bina ile bitişik, sağdaki sınıf ile birlikte sonradan ana binaya ilave edilen ancak kapısı okulun batısına bakan bir sinıf daha bulunmaktadır. Bu sınıf da 4.70 x 7.30 m boyutlarında $34.31 \mathrm{~m} 2$ alan ge-

9 Milli Eğitim Bakanlığı İlköğretim Genel Müdürlüğü, Illköğretim Genel Müdürlüğüne Bağlı Şehir, Kasaba, Köy Ilkokulları ve Bu Okullara Ait Bazı Bilgiler, Milli Eğitim Basımevi, İstanbul 1966, s. 457-758.

10 Resim: 8-9.

11 Bu kahvenin yerinde bugün merhum Yavuz Duman’a ait ev bulunmaktadır. 
nişliğine sahiptir. Okul giriş kapısı kuzeye, lojman giriş kapısı doğuya bakmaktadır. Okulda merkezi ısıtma sistemi olmayıp ısınma her sinıfta ayrı ayrı kurulan sobalar aracılığıla sağlanmıştır. ${ }^{[12]}$

Okul binası dâhilinde bir lavabo yoktur. Lavabo okul dışına yaklaşık $20 \mathrm{~m}$ mesafede olup kız ve erkek öğrenciler için ikişer lavabolu birer bölmesi mevcuttur. Lavabolarda su sistemi olmayıp, 2000’lere kadar taşıma yöntemi ile giderilmiştir. Okul açıldığında su ihtiyacı okul bahçesinde açılan kuyu vasıtasıyla sağlanmış, 1980'lerde ise köye su getirme çalışmaları çerçevesinde okul bahçesine yapılan tek musluklu çeşme; içecek, sulama, temizlik vs. her türlü iş için kullanılmıştır. Lavaboların temizliği okul tarihi boyunca ciddi sorun teşkil etmiştir. Konu öğretmenler kurul defterine de yansımıştır. 1 Eylül 1999 tarihli 56 numaralı kararın 1/d bendi bu konuya ayrılmıştır. İlgili karardan anlaşıldığına göre, tuvaletlerin temizlik yetersizliği sebebiyle kullanılamadığı anlaşılmaktadır. Bu yüzden tuvaletlerin kullanılabilir hale getirilmesi, fosseptik çukurunun temizletilmesi, boruların yenilenmesi, sıva döküntülerinin tamirinin yapılması ve su tesisatı döşenmesi kararı alınmıştır. Ancak tuvalet temizliği ve kullanılabilir hale getirilmesi 1 Eylül 2003 tarihli 66 nolu kararda tekrar konu edildiğine göre problem devam etmektedir.

Bina ve bahçede yapılan değişimler maalesef belge eksikliği sebebiyle takip edilememektedir. Ancak 1 Ekim 1973’ten beri eksiksiz tutulan Öğretmenler Kurul Karar Defteri’nde bazı küçük ipuçlarına rastlanılmaktadır. Deftere göre, okul uygulama bahçesi 1973’ten önce hazırlanmıştır. Çünkü bu tarihten sonra uygulama bahçesindeki ağaçların bakımı rutin bir karar maddesi olarak neredeyse her kurulda kayda geçmiştir. Okul bahçesinin kuzeydoğusunda yer alan mezarlık s1nırında mevcut olan çamların 1973 yılında dikildiği anlaşılmaktadır. Zira 1 Mart 1974 tarihli 2 numaralı kararın 12. maddesi "Çam fidanlarının etrafının çıtalarla çevrilmesi" şeklindedir. Aynı kurulun 10. maddesinde ise "Okulun sıvasının ve dışa açılan kapının önüne yağmurluk yapılmasının zarurî olduğu” ibaresi yer almasına rağmen okul giriş kapısı önüne bu yağmurluk bir türlü yapılamamıştır. 1975’te çam fidanlarının korunması için etrafına muhafaza yapımına devam edilmiştir. Bahçe bakım işleri rutin olarak yapılırken, çamların etrafındaki muhafazalar bir türlü bitirilememiş, önceki yapılan muhafazalar onarılırken kalanların tamamlanması 7 Ocak 1976 tarihli 5 numaralı kararın 1/d bendi ve 5 Ocak 1978 tarihli 6 numaralı kararın 1/s bendi olarak kayıtlara geçmiştir. 1985 yılında ise uygulama bahçesi “Zenginlik Kaynaklarımız" ünitesinin tatbik sahasına dönüştürülmüştür. 1986'da ise bahçe çitleri yenilenmiştir.

Zamanla okul binası da yıpranmıştır. İlk olarak Müdür M. Sıraç Barış okulda genel bir tamirata gerek olduğuna dair İlçe Milli Eğitim Müdürlügü̉ne bir yazı yazmıştır. Barış’ın 8.5.1984 tarih ve 700/13 nolu yazısında okulun durumu, "Oku-

12 Resim 16-19. 
lumuz 1950 yılında ĕ̆itim öğretime açılmış ve 34 yıldır hiçbir onarıma alınmamıştır. Bu uzun zaman içinde okulumuz oldukça yıpranmıştır. Pencere çerçevelerinin büyük bölümü çürümüştür. Müdür odasının taban döşemesiyle lojman salonunun taban döşemesi çürüyerek çökmüştür. Lojman ve okul kapılarının birçoğu kullanılmaz haldedir. İç ve dış duvarlar yıpranmış, bir türlü badana tutmamaktadır. Tuvaleti kesinlikle sağliğa uygun değildir." cümleleriyle ifade edilmiştir. 1987'de müdür odası zemini yenilenmiştir. 1990'da boya badana yapılmış, bu tarihten sonra gereken yerler her yıl boyanmıştır.

9 Mart 1992'de yapılan okul teftişinde okulun genel durumu hakkında; “Okul üç dönümlük bahçe içerisinde yer almıştır. Okul binası üç dershane, bir idare odasından meydana gelmiştir. Okul binası salonunda Atatürk Köşesi bulunmaktadır. Yangin köşesi araç gereçler teşekkül ettirilmiştir. Sonradan eklenen dershanelerin birinin tahta zemininde çökme, ikinci dershanenin çatısı bulunmadiğı için akma görülmüş ve onarıma ihtiyaç duyulduğu kanaatine varılmıştır” şeklinde bir tespitte bulunulmuştur. Bunun üzerine Okul Müdürü Hüseyin Duman ${ }^{[13]}$ harekete geçerek 27.11.1992 tarih ve 700/32 sayılı yazısında, "Okulumuz dershanelerinden birinin taban döşemesi ve pencere çerçeveleri, diğerinin tavanı, okulun tamamının elektrik tesisatının yenilenmesine ihtiyaç vardır. Okulun tuvaleti köy imkânları ile yapılmış olup kullanım ve sağlık açısından uygun değildir." diyerek İlçe Milli Eğitim Müdürlügü̈nden okulun tamiratı konusunda yardım istemiştir. Fakat istenen onarım bir türlü gerçekleştirilmemiştir. Zira bir yıl sonra okul teftişi sırasında dersliklerden birinin tabanının çökmüş olduğu, diğerinin tavanının aktığ 1 , elektrik tesisatındaki arıza nedeniyle okul elektriklerinin yanmadığı tespit edilmiştir.

Benzer bir yazı sekiz yıl sonra Okul Müdürü Hüseyin Duman tarafından yeniden yazılmıştır. Duman 8.5.2000 tarih ve 715/19 sayılı "Okulun Onarıma Alınması" başlıklı yazısında, "Okulumuz 1950 yılında öğretime açılmış, 3 derslik ve lojmandan oluşan bir binadır. Uzun zaman içinde bazı bölüm ve kısımlar yıpranıp eskidiğinden eğitim öğretim güçlükle sürdürülmektedir." diyerek gerekli tespitin yapılarak okulun onarıma alınmasını istemiştir. İlgili yazıya göre okuldaki problemler şunlardır:

1-Bir dersliğin taban döşemesi çürümüş çökmek üzeredir.

2-Aynı dersliğin üç pencere çerçevesi çürümüş olup kullanılmaz durumdadır.

3-Çatının akan yerlerinin onarılması gerekmektedir.

4-Dış cephe eski boyalarının kazınarak, dış cephe boyası ile boyanması gerekmektedir.

13 Hüseyin Duman 2 Kasım 2021 Pazartesi günü elim bir trafik kazası sonucu hayatını kaybetmiştir. 
$\mathrm{Bu}$ yazıya rağmen istenen tadilat yapılamamış, geçici çözümlerle durum idare edilmeye çalışılmıştır. Mesela 5 Eylül 2000'de okul müdürlügüne 1,5 m3 mamul çam kereste, 2 teneke diş cephe boyası teslim edilmiştir. Ancak sıkıntılar ilerleyen yillarda da devam etmiştir.

Okul 18 Ağustos 1997 tarihli 4306 sayılı kanun gereğince İlköğretime dönüştürülmüştür. ${ }^{[14]}$ Ancak dönüşüm okul adı, mührü ve kaşesiyle sınırlı kalmış, okulda fiziki bir değişiklik yapılmamıştır. ${ }^{[15]}$ Okulda 1951'den, taşımalı sistem sebebiyle kapandığı yıl olan 2005-2006 eğitim öğretim yılı sonuna kadar eğitim öğretim faaliyetine devam edilmiştir.

\section{B-Öğretmenler}

Büyük Atatürk daha Milli Mücadele’nin hemen ardından 27 Ekim 1922'de Bursa Şark Tiyatrosu Salonu'nda 472 ilkokul öğretmeni ile bir araya gelmiş ve onlara çok önemli bir görev yüklemiştir: "Ordularımızın ihraz ettiği zafer, sizin ve sizin ordularınızın zaferi için yalnız zemin hazırladı. Hakikî zaferi siz ihraz ve idame edeceksiniz ve behemehâl muvaffak olacaksınız." Böylece ülkenin kurtarıcısı, ülkenin geleceğini öğretmenlerin ellerine emanet etmiştir. Bu görevde köy öğretmenleri en ön safta yer almışlardır. Söz konusu görev Tekkesarmaşık İlkokulunda görev yapan öğretmenler için de geçerlidir. Nitekim geçmişte köy öğretmeni diye bir kavram vardır ve bu kavramın içi boş değildir. Köy öğretmenleri hem çevreye örnek olur hem de öğrencilerinin her şeyi ile ilgilenirlerdi. Mesela okulun 1 numaralı Öğretmenler Kurul Kararı̉nın 5. maddesi: "Çevresinin özelliklerine göre giyim kuşam ve davranışlar ayarlanacak, örnek olunacak” şeklindedir.

Okul açıldığında ilk öğretmen köy hafızasında kendisine unutulmaz bir yer bırakan ve daha sonra da köyle irtibatını hiç kesmeyen 19 yaşında bir genç olan Hüseyin Ataklı'dır. Hüseyin öğretmen Kavak Susuz Köyü nüfusuna kayıtlıdır. Tekkesarmaşık'tan sonra 1958'de okul açılan Lengerli Köyüne, oradan da Bafra'ya tayini çıkmış, kariyerini 60'ların sonunda Almanya'ya gönderilen öğretmen grubu içinde yer alarak sürdürmüştür. ${ }^{[16]}$ 1958-59 eğitim öğretim yılına kadar birleştirilmiş sınıfta öğrencilere ders veren Hüseyin Ataklı’nın yerine Osman Demirbaş atanmıştır. Demirbaş'tan sonra 60'lı yıllarda sırayla Hasan Çubukçu ve Cahide Müderrisoğlu öğretmen olarak görev yapmışlardır.

5 öğretmenin görev süreleri Tekkesarmaşık Köyü İlkokulu Öğretmenler Sicil Defteri’nde yer alırken, diğer öğretmenlerin okuldan ne zaman ayrıldıkları Tekke-

14 Resmi Gazete, 18 Ağustos 1997, Sayl: 23084, s. 2-3.

15 Resim: 14-15.

16 Resim 1; Anlatı Selime Afet Yılmaz, 1939 Bafra Doğumlu, okula 1950 yاlında kaydolan 5 numaralı öğrencidir. Ancak yaşı büyük olduğu için ikinci sınıfın sonunda okula veda etmek zorunda kalmıştır. 
sarmaşık Köyü İlkokulu Öğretmenler Karar Defteri değerlendirilerek elde edilmiştir. Öğretmenlerden Resul Şahin 3 Eylül 1975’te başladığ görevine sekiz yıl devam ettikten sonra 19 Ocak 1983'te 243.1/4590 tarih ve sayılı yazı ile Ballıca (19 Mayı) İlkokulu Müdürlügüủne atanmıştır. Emine Karaduman’ın ise 16 Ocak 1981'de başladığı görevi kısa sürmüss, o 10 Ekim 1983 tarih ve 243.1/13 sayılı yazı ile Kemah Eriç İstasyon Mahallesi İlkokuluna nakledilmiştir. Devrim Doğanay'ın ${ }^{[17]} 9$ Eylül 1985 'te başlayan görevi 8 Ocak 1993’te son bulmuştur. Doğanay, bu tarihten sonra görevini Bafra Sarıçevre İlkokulunda sürdürmüştür. Tekkesarmaşı İlkokulunda uzun süre görev yapan öğretmenlerden biri de Yusuf Akyürek’tir. Akyürek 5 Eylül 1986'dan 17 Ocak 1996’ya kadar okulda görev yapmıştır. Onun sonraki görev yeri Bafra Cumhuriyet İlköğretim Okulu olmuştur. Okulda en uzun süre görev yapan öğretmen ise Hüseyin Duman ${ }^{[18]}$ olmuştur. Duman 16 Eylül 1986'da başladığ görevini 2005 yılına kadar aralıksız 19 yıl sürdürmüştür. Duman uzun süren öğretmenlik ve müdürlük görevini 23 Ağustos 2005’te Emrullah Atalar’a devretmiştir. Öğretmenlerden Nejat Çakır'da okulda sekiz yılı dolduran öğretmenlerdendir. O, 14 Eylül 1993 ilâ 2 Kasım 2001 yılları arasında Tekkesarmaşık İlkokulunda görev yapmış ve daha sonra Bafra 50. Yıl İlkokuluna nakil gitmiştir.

Mevcut Öğretmenler İzin Defteri incelendiğinde, öğretmenlerin çoğunun görevlerini titizlikte yerine getirdiği görülecektir. Devamsızlık genel olarak değerlendirildiğinde erkek öğretmenlerin genellikle dış görevler, hizmet içi kurslar, ölüm, mahkeme davetiyesi gibi sebeplerle; kadın öğretmenlerin ise hastalık ve doğum gibi sebeplerle devamsızlık yaptıkları anlaşılmaktadır.

2 öğretmen olduğunda 1, 2 ve 3. sinıfları 1 öğretmen, 4-5. sinıfları 1 öğretmen okutmuştur. 3 öğretmen olduğunda 1. sinıflar 1 öğretmen, 2-3. sinıflar 1 öğretmen, 4-5. sınıflar 1 öğretmen tarafından alınmıştır. 4 öğretmenin olduğu yıllarda 4-5. s1nıflar 1 öğretmen diğer sınıflar l’er öğretmen tarafından paylaşılmıştır. 2 öğretmenin olduğu 1972 öncesinde ve 4 öğretmenli eğitimin olduğu 3 yıl boyunca okulda ikili eğitim yapılarak derslik problemi çözülmüştür. 
Tekkesarmaşık Köyünde Görev Yapan Öğretmenler

\begin{tabular}{|c|c|c|c|c|c|}
\hline Ad $_{1}$ & $\begin{array}{c}\text { Doğum } \\
\text { Yilı }\end{array}$ & $\begin{array}{l}\text { Doğum } \\
\text { Yeri }\end{array}$ & $\begin{array}{c}\text { Öğretmenliğe } \\
\text { Başlama }\end{array}$ & $\begin{array}{c}\text { Göreve } \\
\text { Başlama }\end{array}$ & $\begin{array}{c}\text { Görevden } \\
\text { ayrilma }\end{array}$ \\
\hline Hüseyin Ataklı & & Kavak & 1931 & 10.11 .1950 & 1958 \\
\hline Osman Demirbaş & & & & 1958 & 2.11 .1965 \\
\hline Osman Özcan & & & & 1.11 .1965 & 10.5.1966 \\
\hline Hasan Çubukçu & & & & 1966 & 1970 \\
\hline Cahide Müderrisoğlu & & & & 1966 & 1970 \\
\hline Ahmet Fevzi Erdal & & & & 1966 & 17.8.1967 \\
\hline Sadrettin Çiçek & 1944 & Şavşat & 25.07.1967 & 29.08 .1970 & 1975 \\
\hline Sermin Çiçek & 1949 & Şavşat & 31.07 .1969 & 08.09 .1970 & 1975 \\
\hline Salim Yavuz & 1953 & Alaçam & 19.09.1971 & 19.09.1971 & 1975 \\
\hline Gülseren Aktaş & - & - & - & 08.10 .1973 & 1976 \\
\hline Resul Şahin & 1950 & Şavşat & 09.12 .1970 & 16.09 .1975 & 19.12 .1983 \\
\hline Erol Tokur[19] & 1952 & Bafra & - & 05.01 .1976 & 1980 \\
\hline Kerime Kul & - & - & - & 09.11 .1976 & 1977 \\
\hline Nevin Kuruçay & - & - & - & 12.02.1979 & 1979 \\
\hline Kâmil Sarı & 1951 & Alaçam & 23.10 .1972 & 19.11 .1980 & 1985 \\
\hline Emine Karaduman & 1958 & Bafra & 1978 & 16.01 .1981 & 10.10 .1983 \\
\hline M. Sıraç Barış & 1954 & Kozluk & 28.08 .1974 & 09.01 .1984 & 2.10 .1986 \\
\hline Devrim Doğanay & 1960 & Bafra & 16.11 .1979 & 09.09 .1985 & 08.02 .1993 \\
\hline Yusuf Akyürek & 1959 & Bafra & 28.02.1979 & 05.09 .1986 & 17.02.1996 \\
\hline Hüseyin Duman & 1960 & Bafra & 20.11 .1979 & 16.09 .1986 & 23.08 .2005 \\
\hline Nejat Çakır & 1959 & Alaçam & 05.01 .1981 & 14.09 .1993 & 02.11 .2001 \\
\hline Emrullah Atalar & 1971 & Samsun & 23.03.1998 & 08.02 .2002 & 2006 \\
\hline Türkan Canikli Yıldırım & & & & 2005 & 02.10 .2007 \\
\hline
\end{tabular}

19 Resim 2. 


\section{C-Öğrenciler}

\section{1-Açılış ve İlk Öğrenciler ${ }^{[20]}$}

Tekkesarmaşık ilkokulunun ilk sınıfı 62 öğrenciden oluşmaktadır. Öğrencilerin tamamının kaydı 10 Kasım 1950 tarihlidir. Ancak 10 Kasım Cuma gününe denk geldiğinden, okulda fiili eğitim 13 Kasım 1950 Pazartesi günü resmen başlamıştır. 62 öğrencinin tamamı köy halkının çocukları olup, ailelerinin geçim kaynakları çiftçiliktir. Öğrencilerin hepsinin doğum yeri Bafra gösterilmiştir. Okula kaydolan öğrencilerin 47’si erkek (\% 75,8), 15’i (\% 24,2) kızdır. Kız öğrencilerin azlığına bakarak bazı ailelerin başlangıçta kızlarını okula göndermedikleri anlaşılmaktadır.

Bu ilk grupta mezun olan öğrenci sayısı da oldukça azdır. Öğrencilerden 3’ü 1. sınıfta kalmış 2. sınıfa geçememiştir. 1 öğrenci 4 yıl, 1 öğrenci ise 5 yıl üst üste 1. s1nıfta kalmıştır. 11 öğrenci 2. sınıfta kalmış, 3. sınıfa geçememiştir. Bazı öğrenciler yaş veya sınıf tekrarı sebebiyle 2. sınıftan sonra okulu bırakmak zorunda kalınca 3. sınıfa 39, 4. sınıfa 33 kişi devam etmiş ve 33 kişiden 28'i mezun olmayı başarmıştır. Mezun öğrenci oranı \% 45,16 olurken, kayıp \% 54,83 olmuştur. Mezunların 5’i kız ( \% 17,86), 23'ü $(\% 82,14)$ erkektir. 1950'de okula kaydolan kız öğrenciler içinde mezun oranı \% 33,33 iken, erkek öğrenciler arasında \% 48,93’tür.

Okula devamın yanı sıra başarı konusunda da sıkıntı mevcuttur. Zira mezun öğrenciler arasında doğrudan sınıfı geçen $12(\% 42,85)$ kişidir, diğer öğrenciler sınıf tekrarı yapmak zorunda kalmışlardır. Sınıf tekrarı yapmadan bir üst sınıfa geçen öğrencilerin tamamı erkektir. Bu öğrencilerin 3'ü "pekiyi”, 8'i “iyi”, 1’i ise "orta” derece ile mezun olmuştur. Sınıf tekrarı yaparak mezun olanlardan 2'si 2 kez 1. sınıf tekrarı yaparken, 11'i 1. sınıf, 3’ü ise 4.cü sınıfa yeniden devam etmiştir.

İlk kayıt olan öğrencilerden 6'sı çeşitli sebeplerle başka okullara nakledilmiştir. 16’sı erkek, 8'i kız olmak üzere 24 öğrenci ise 5955 sayılı kanun gereğince yaşı okul çağını geçtiği için velisinin isteği ile okuldan kaydı silinmiştir. Bu oran kayıt olan öğrencilerin \% 38.70’i gibi yüksek bir orana ulaşmaktadır. Öğrencilerden 1 erkek, 1 kız öğrenci, resmî olarak evlendiği için aynı kanuna istinaden 17 Kasım 1952'de 1952-53 eğitim öğretim yılı başında 3. sınıfa başlamadan okuldan ayrılmıştır. 1 kız öğrenci hastalık 1 erkek öğrenci ise okulu terk suretiyle eğitimlerini tamamlayamamışlardır. Öğrencilerden 6'sının vesikalık fotoğrafı varken, 53'ünün yoktur. 6 fotoğrafin tamamı da mezun öğrencilere aittir. Fotoğrafı olan öğrencilerden 5 ’i erkek 1'i kızdır.

İlk öğrencilere Türkçe, Tarih-Coğrafya-Yurttaşlık Bilgisi, Tabiat Bilgisi, Aile Bilgisi, Hayat Bilgisi, Aritmetik-Geometri, Resim İş, Din Bilgisi, Yazı, Müzik, Jimnastik 
dersleri verilmiştir. Bunun yanında Hal ve Gidiş, Temizlik, İntizam ve Diş Koruma gibi davranış dersleri de nota tabidir. Okul tam gün olup, öğle öncesi dersler 08:3011:45, öğle arası (öğrencilerin deyimiyle öğle paydosu) 11:45-12:55, öğle sonrası dersler 12:55-14:50 saatleri arasında yapılmıştır.

\section{2-Yıllara Göre Öğrenci Sayıları ${ }^{[21]}$}

1951'de okula hiçbir kayıt yapılmazken 1952'de 8 öğrenci kayıt yapmıştır. Ö $\breve{g}-$ rencilerden 7'si erkek 1'i kızdır. 1952 kayıtlılardan 5'i mezun olmuş, 1'i babası öldügü için 3. sınıfta okulu bırakmış, 1’i yaşı öğrenim çağını geçtiği için kayıt sildirmiş, 1’i ise ailesi İstanbul'a göç ettiği için okulu bırakmıştır.

1953’te okula kaydolan öğrenci sayısı 14 olup, öğrencilerin 5’i kız 9'u erkektir. 1953 kayıtlılardan 10'u okuldan mezun olmayı başarmıştır. 1 kız öğrenci nişanlanması sebebiyle okulu 3. sınıftan sonra bırakmıştır. Üstelik onun dersleri pekiyi ve iyidir. 1 kız öğrenci de ailesi 1958 yılı içinde İstanbul’a göç ettiği için 4. sınıf sonunda okulu bırakmak zorunda kalmıştır. 2 kız öğrenci ise öğrenim yaşını geçtiği için okulla ilişkileri kesilmiştir.

1954’te 12 öğrenci okula kaydolmuş olup, öğrencilerin 4'ü kız 8’i erkektir. Bu öğrencilerden 8'i mezun olmuştur. Mezun olamayanların 3’ü kız 1'i erkektir. 1 öğrenci ailesi Ayazma Köyü’ne göç ettiği, 1'i akıl hastalığı, 1'i ise 5 yıl üst üste 1. sinıfta kaldığ 1 için okulu bırakmak zorunda kalmıştır. Okulu tamamlayamayan erkek öğrenci ise görme engelli olduğu için okula devam edememiştir.

1955 ’te 14 öğrenci kayıt olmuştur. Öğrencilerin 3’ü kız 11'i erkektir. Bu öğrencilerden 4'ü hariç diğerleri mezun olmuştur. Maalesef 2 kız öğrenci hayatını kaybettiği için listeden silinmiştir. Hastalık nedenleri bilinmemektedir. 1 öğrenci ailesi İstanbul'a göç ettiği için 1 öğrenci ise öğrenim çağını geçtiği için okula devam edememiştir.

1956'ta tamamı erkek 7 öğrenci okula kaydolmuştur. Öğrencilerden 2'si 13 Ekim 1956 tarihinde Bafra Atatürk İlkokulundan nakil gelmiştir. Öğrencilerden 1’i 1. sınıfta üst üste 3 yıl kaldığı için okulla ilişiği kesilmiş, diğerleri mezun olmuştur.

Okula 1957 kayıtlı 8 öğrenci vardır ve 1'i hariç hepsi mezun olmayı başarmıştır. 1 öğrenci ailesi İzmir'e göç ettiği için okula devam edememiştir. Öğrencilerden 2'si k1z 6's1 erkektir.

1958'te okula kayıt olan öğrenci sayısı 23'tür. Öğrencilerden 2'si kızken 21'i erkektir. Kızların 2'si de mezun olmayı başarırken, erkeklerden 17'si okulu tamamla-

21 Tekkesarmaşık Köyü Illkokulu Öğrenci Kütüğü, I. 
yabilmiştir. 2'si öğrenim çağını doldurduğu, 1'inin ailesi Vezirköprü’ye, 1'inin ailesi de İstanbul'a göç ettiği için okulu tamamlayamamıştır.

1959'da 2'si kız 9’u erkek 11 öğrenci kaydolmuş, tamamı da mezun olmuştur.

1960’ta 15’i kız 19 öğrenci kaydolmuş, ancak 7’si kız 3’ü erkek toplam 10 öğrenci mezun olabilmiştir. $5 \mathrm{kız}$ öğrenci öğrenim yaşını doldurduğu, 1'si velisinin isteği, 1'i Samsun Irmak İlkokuluna nakil gittiği için okula devam edemezken, 2 öğrencinin okulu bırakma gerekçesi belli değildir.

1961'de 6 kız 7 erkek toplam 13 öğrenci okula kaydolmuş, 3’ü erkek 3'ü kız olmak üzere 6 öğrenci mezun olmuştur. Öğrencilerden 3’ü öğrenim çağını doldurduğu, 1'inin ailesi İstanbul'a göç ettiği için okulu tamamlayamaz iken, 1 öğrencinin kayıt silinme gerekçesi oldukça ilginçtir. Hakkında adından başka bir bilgi bulunmayan bu öğrenci kimsesi olmadığ 1 için 3.cü sınıftan sonra okulla ilişiği kesilmiştir. 2 öğrencinin ise kayıt sildirme gerekçesi belli değildir.

1962'de 5’i kız 10’u erkek 15 öğrenci kaydı söz konusudur. 1 öğrenci eğitim görürken vefat etmiş, 3 öğrenci başka okullara nakil gitmiş, 2'si yaşı öğrenim çağını geçtiği için okulu bırakmıştır. 1'nin okul bırakma sebebi belli değildir. 4'ü kız 4'ü erkek 8 öğrenci ise mezun olmuştur.

1963’te 13’ü erkek 9’u kız 22 öğrenci kayıt olmuş, ancak sadece 6 erkek 3 kız öğrenci mezun olabilmiştir. 5'i başka okullara nakil edilirken, 1'i ailesi İzmir'e göç ettiği için okula devam edememiştir. 7'sinin okulu neden bıraktığı belli değildir.

1964'te 4’ü kız 5’i erkek 9 öğrenci okula kaydedilmiş, fakat mezun öğrenci görünmemektedir. Bu tarihten itibaren kayıtlarda bir eksiklik söz konusudur. Zira çoğu öğrencinin 2. sınıftan sonraki notları deftere kaydedilmemiştir.

1965 'te 4'ü kız 6'sı erkek 10, 1966'ta 12'si kız 22'si erkek 34, 1967'de 10'u kız 17'si erkek 27, 1968'de 7’si kız 13'ü erkek 20 öğrenci kaydolmuştur.

1969-1982 yılları arası bir değerlendirme yapılamamıştır. Çünkü 1970’li yıllara ait öğrenci sayılarına ulaşılamamıştır.

1982-83 eğitim öğretim yılında okulda 3 öğretmen vardır. Öğretmenlerden Emine Karaduman 1. sinıfları okuturken 9'u kız 6'sı erkek 15 öğrencisi, Kamil Sari ${ }^{[22]} 2$ ve 3. sinıfları okutmaktadır ve 14'ü kız 16'sı erkek 30 öğrencisi, Okul Müdürü Resul Şahin ise 4 ve 5. sinıfları okutmakta olup 15’i erkek 9’u kız 24 öğrencisi bulunmaktadır. Bu durumda okulda 32'si kız, 37'si erkek olmak üzere 69 öğrenci

22 Resim 3. 
mevcuttur. ${ }^{[23]}$

1983-84 yılında okula kayıtlı 70 öğrenci mevcuttur. Ancak sadece Kamil Sarı’nın okuttuğu sınıf öğrenci sayılarına ulaşılmıştır. Sarı, 1983-84 eğitim öğretim yılında 1 ve 2. sınıfları okutmaktadır. 18'i kız 10’u erkek olmak üzere 28 öğrencisi vardır. Öğrencilerden 16’sı 1. sınıf, 12'si ikinci sınıf öğrencisidir.

1984-85 eğitim öğretim yılında okulda 35’i kız 27’si erkek olmak üzere toplam 62 öğrenci vardır. Öğrencilerden 14 ’ü kız, 13’ü erkek toplam 27 öğrenci 4 ve 5 . sinifa devam etmektedir.

1985-86 eğitim öğretim yılında sadece öğretmen Devrim Doğanay’ın sınıf mevcudu sayısına ulaşılabilmiştir. Doğanay 1, 2 ve 3. sınıfları okutmaktadır. Sınıfında 17'si kız 23'ü erkek olmak üzere 40 öğrenci vardır. 1 sınıfta 13, 2. sinıfta 7, 3. sınıfta 19 öğrenci bulunmaktadır, 1 öğrencinin hangi sınıfa devam ettiği tespit edilememiştir.

1986-87 eğitim öğretim yılında 1. sınıfta 10 kız, 13 erkek; 2 ve 3 . sinıfta 6 kız, 12 erkek; 4 ve 5 . sinıfta 19 kız, 11 erkek, toplamda 35 kız 36 erkek olmak üzere 71 öğrenci okula devam etmektedir.

1987-88 eğitim öğretim yılında 1. sınıfta 9 kız, 10 erkek; 2 ve 3 . sınıfta 16 kız, 15 erkek; 4 ve 5 . sinıfta 6 kız, 14 erkek, toplamda 31 kız 39 erkek olmak üzere 70 öğrenci okula devam etmektedir.

1988-89 eğitim öğretim yılında okulda 3 öğretmen vardır. Öğretmenlerden Hüseyin Duman 1. sinıfları okuturken 14'ü kız 15’i erkek 29 öğrencisi, Yusuf Akyürek 2-3. sınıfları okutmaktadır ve 10’u kız 11'i erkek 21 öğrencisi vardır. Devrim Doğanay ise 4-5. sınıfları okutmaktadır, ancak onun öğrenci sayısına ulaşılamamiştır.

1989-90 eğitim öğretim yılında okulda 3 öğretmen vardır. Öğretmenlerden Devrim Doğanay 1. sınıfları okuturken 8'i kız 1'i erkek 9 öğrencisi mevcuttur. Hüseyin Duman 2-3. sinıfları okutmaktadır ancak onun öğrenci sayısına ulaşılamamıştır. Yusuf Akyürek ise 4-5. sınıfları okutmaktadır ve 14’ü kız 16’sı erkek 30 öğrencisi vardır.

1990-91 eğitim öğretim yılında okulda 3 öğretmen vardır. Öğretmenlerden Hüseyin Duman 1. sinıfları okuturken 4'ü kız 9'u erkek 13 öğrencisi mevcuttur. Devrim Doğanay 2-3. sınıfları okutmaktadır ancak onun öğrenci sayısına ulaşıla-

23 Bundan sonraki sayısal bilgiler Tekkesarmaşık Köyü Ilkokulu Öğretmenler Teftiş Rapor Klasörü’nden elde edilmiştir. 
mamıştır. Yusuf Akyürek ise 4-5. sınıfları okutmaktadır ve 16’sı kız 119'u erkek 35 öğrencisi vardır.

1991-92 eğitim öğretim yılında okulda 29 kız, 27 erkek olmak üzere toplam 56 öğrenci 3 öğretmen mevcuttur.

1992-93 eğitim öğretim yılında okulda 25 kız, 23 erkek olmak üzere toplam 48 öğrenci ve 2 öğretmen mevcuttur.

1993-94 eğitim öğretim yılında okulda 23 kız, 25 erkek olmak üzere toplam 48 öğrenci ve 3 öğretmen mevcuttur.

1994-95 eğitim öğretim yılında okulda 24 kız, 25 erkek olmak üzere toplam 49 öğrenci ve 3 öğretmen mevcuttur.

1995-96 eğitim öğretim yılında okulda 21’i kız 19’u erkek olmak üzere toplam 40 öğrenci, 3 öğretmen vardır. Öğrencilerden 2'si kız 3’ü erkek toplam 5 öğrenci 1. sinıfta, 19 öğrenci 2-3. sinıflarda, 6'sı kız 8'i erkek toplam 14 öğrenci ise 4-5. sinıfta eğitim görmektedir. 1. sinıfa Yusuf Akyürek, 2-3. sinıflara Hüseyin Duman, 4-5. sınıflara ise Nejat Çakır tarafından eğitim verilmektedir.

1996-97 eğitim öğretim yılında okulda 22'si kız, 20’si erkek olmak üzere toplam 42 öğrenci ve 2 öğretmen mevcuttur. Öğrencilerden 13'ü kız 13'ü erkek toplam 26 öğrenci 1, 2 ve 3. sınıflarda, 16 öğrenci ise 4-5. sinıflara devam etmektedir. 1, 2 ve 3. sınıflara öğretmen Nejat Çakır, 4-5. sınıflara ise Hüseyin Duman tarafından eğitim verilmektedir.

1997-98 eğitim öğretim yılında okulda 22'si kız, 19’u erkek olmak üzere toplam 41 öğrenci ve 2 öğretmen mevcuttur. Öğrencilerden 11'i kız 11'i erkek toplam 22 öğrenci 1, 2 ve 3. sinıflarda, 18 öğrenci ise 4-5. sinıflara devam etmektedir. 1, 2 ve 3. sınıflara öğretmen Nejat Çakır, 4-5. sınıflara ise Hüseyin Duman tarafından eğitim verilmektedir.

1998-99 eğitim öğretim yılında okulda 18’i kız, 14’ü erkek olmak üzere toplam 32 öğrenci ve 2 öğretmen mevcuttur. Öğrencilerden 13'ü kız 9’u erkek toplam 22 öğrenci 1,2 ve 3. sinıflarda, 10 öğrenci ise 4-5. sinıflara devam etmektedir. 1, 2 ve 3. sınıflara öğretmen Nejat Çakır, 4-5. sınıflara ise Hüseyin Duman tarafından eğitim verilmektedir.

1999-2000 eğitim öğretim yılında okulda 17’si kız, 17’si erkek olmak üzere toplam 34 öğrenci ve 2 öğretmen mevcuttur. Öğrencilerden 10'u kız 8'i erkek toplam 18 öğrenci 1,2 ve 3. sinıflarda, 16 öğrenci ise 4-5. sinıflara devam etmektedir. 1 , 
2 ve 3. sınıflara Nejat Çakır, 4-5. sinıflara ise Hüseyin Duman tarafından eğitim verilmektedir.

2001-2002 eğitim öğretim yılında öğrenci sayısının oldukça düştüğü gözlenir. Bu eğitim öğretim yılında 9'u yeni kayıt 1'i nakil toplam 10 öğrenci okula kayıt edilmiştir. Öğrencilerin 5’i erkek, 4’ü kızdır. Nakil öğrenci ise erkektir. Bu öğretim yılında 20'si kız, 16'sı erkek olmak üzere toplam 36 öğrenci okula devam etmektedir. Öğrencilerden 13'ü kız 8'i erkek toplam 21 öğrenci 1, 2 ve 3. sinıflarda, 15 öğrenci ise 4-5. sinıflara devam etmektedir. 1, 2 ve 3. sinıflara Nejat Çakır, 4-5. sınıflara ise Hüseyin Duman tarafından eğitim verilmektedir.

2002-2003 eğitim öğretim yılında 1. sınıfta 1 erkek 3 kız, 2. sınıfta 4 erkek 4 kız, 3. sinıfta 2 erkek $8 \mathrm{kız}, 4$. sinıfta sadece 6 erkek, 5 . sinıfta ise sadece $5 \mathrm{kiz}$ olmak üzere, 13'ü erkek 20'si kız toplam 33 öğrenci mevcuttur. Bu eğitim öğretim yılında 1, 2 ve 3. sinıfları öğretmen Emrullah Atalar, 4-5. sinıfları Hüseyin Duman okutmaktadir.

2003-2004 eğitim öğretim yılında 1. sınıfta 5 erkek 5 kız, 2. sınıfta 2 erkek 2 kız, 3. sinıfta 4 erkek 4 kız, 4 . sinıfta 2 erkek 8 kız, 5. sinıfta 6 erkek 0 kız olmak üzere, 19'1 erkek 19'u kız toplam 38 öğrenci mevcuttur.

2004-2005 eğitim öğretim yılında 1. sınıfta 3 erkek 3 kız, 2. sinıfta 5 erkek 5 kız, 3. sinıfta 2 erkek 2 kız, 4 . sınıfta 4 erkek 4 kız, 5. sınıfta 2 erkek 8 kız olmak üzere, 16 'sı erkek 22'si kız toplam 38 öğrenci mevcuttur. İkinci yarıl öğrenci sayısı 36 gerilemiş, 1 kız ve 1 erkek öğrenci başka okullara nakil gitmiştir. Bu eğitim öğretim yılında 1, 2 ve 3. sinıfları öğretmen Emrullah Atalar, 4-5. sınıfları Hüseyin Duman okutmaktadir.

2005-2006 eğitim öğretim yılında 1. sınıfta 2 erkek 1 kız, 2 . sinıfta 4 erkek 3 kız, 3. sinıfta 5 erkek 4 kız, 4 . sinıfta 1 erkek 2 kız, 5. sinıfta 4 erkek 5 kız olmak üzere, 16’sı erkek 15’i kız toplam 31 öğrenci mevcuttur. Fakat yılsonunda öğrenci sayısı 14 'ü kız, 11'i erkek olmak üzere toplam 25 öğrenciye düşmüştür. Okulun son yılı olan bu eğitim öğretim yılında sadece bir öğretmen mevcuttur. Bu yüzden 7 öğrenci başka okullara nakil gitmiş, sadece 1 öğrenci gelmiştir.

2000’li yıllarla birlikte okuldaki gerek fizikî gerekse öğretmen yetersizliği okula olan ilgiyi azaltmış, imkânı olan aileler çocuklarını Bafra merkezdeki okullara nakletmişlerdir. Bir başka faktör de köy gençlerinin geçim kaygıları sebebiyle köyü terk etmeleri sonucu köy nüfusunun azalmasıdır. Zaman zaman çeşitli sebeplerle okula geri dönüşler yaşansa da nakiller daha fazladır. 


\section{3-Öğrenci Profili ve Okulda Yaşam ${ }^{[24]}$}

Öğrenciler büyük çoğunlukla Tekkesarmaşık, Benliuşağı ve Sarmaşık Mahallesi sakinlerinden oluşmaktadır. Daha sonra önce Sarmaşık, 1990'larda da Benliuşağı'na okul yapılmış ${ }^{[25]}$, böylece tüm öğrenciler Tekkesarmaşıklılardan oluşmuştur. Öğrencilerin neredeyse tamamının ailesi çiftçilikle geçinmektedirler. 1950-1970 arasında okula devam eden 368 öğrenciden sadece 7'sinin ailesi başka bir işle geçimini sağlamaktadır.

Tekkesarmaşık İlkokulu öğrencileri mutlu çocuklardır. Okul onlar için akademik bilginin öğretildiği bir yer olmanın ötesinde sosyalleşme ve oyun yeridir. Genellikle aile işlerinden oyun oynamaya vakit bulamayan veya coğrafî uzaklık sebebiyle oyuna vakit bulamayan çocuklar bu ihtiyacı okulda karşılamışlardır. Bu yüzden ortalama akademik başarıya sahip her öğrenci okulun açılmasını dört gözle beklemiştir. Yaz tatili, şehirdeki akranlarının tersine onlar için işin başlaması demektir. Özellikle tarımda makineleşmenin yeterli olmadığı 1990’lar öncesi bu durum aşağı yukarı tüm köy okul öğrencileri için geçerlidir. Tekkesarmaşık İlkokulunda herhangi bir spor tesisi olmadığı için oyun alanı okul bahçesiydi. Teneffüslerde bilye, saklambaç, futbol (ya da öğrenci deyimi ile top), ip atlama, yakan top, seksek, mendil kapmaca, dombili, beş taş, encik mencik vs. oyunlar oynanırdı. Erkek çocuklar için top bulunabildiği sürece futbol, kız çocuklar için sek sek ve ip atlama teneffüslerin vazgeçilmez oyunlarıydı. 1990'lardan sonra oyunlara voleybol ve satranç da eklenmiştir.

Öğrenciler için en büyük problem ulaşımdır. 4-5 km’lik bir yarıçapı kapsayan okul bölgesinden yaz kış okula ulaşmak her zaman sıkıntılı olmuştur. Çocukların tamamı evlerinden okula yürüyerek gelmişlerdir. Köy yolu stabilize olup, asfalt değildi (hâlâ da değildir). Özellikle kışın kar, ilkbahar ve sonbaharda yoğun yağış yolları çamura çevirdiği için öğrenciler büyük güçlük çekerek okula ulaşırdı. Okula gelindiğinde ilk iş ayakkabı çamurlarını silmekti. Ayakkabı silmek belki de okula dair öğrencilerin en sevmediği şeydi.

Öğretmenler daima saygı duyulan, sevilen ve aynı zamanda korkulan kişilerdi. Çoğu zaman ailesinden dahi görmedikleri sevgi ve ilgiyi öğretmenlerinden gören öğrenciler öğretmenlerini çok sever ve onlara gönülden bir bağlılık duyarlardı. Bu yüzden öğrencilerin neredeyse tamamının en büyük hayali büyüyünce öğretmen olmak olmuştur.

Okulda her öğrencinin kişisel gelişim özelliklerine göre dâhil olabilecekleri 4

\footnotetext{
24 Buradaki bilgiler şahsî deneyimlerim ve farklı yıllarda okulda öğrenim görmüş öğrencileri intibahlarından derlenmiştir.

25 Resim 22-23.
} 
temel eğitsel kol faaldi. Bunlar spor, temizlik, Kızılay ve kütüphane kollarıydı. Öğrenciler kol faaliyetlerinde gönüllü olarak yer almışlardır. Bir öğrenci sportif alanda becerili ise spor koluna, akademik başarısı yüksek ise kütüphane koluna, diğer çocuklara göre temizliğine daha fazla önem veriyor ise temizlik koluna, yardımsever ise Kızılay koluna katılabilirdi. Öğrenci temizlik kolunda ise ders başlamadan mendil ve tırnak kontrolü gibi işler temizlik kolu başkanı tarafından yapılırdı. Kızılay kolundaki öğrencinin temel işi öğrencilere Kızılay Pulu dağıtmak ve tahsilini yapmaktı. Kütüphane kolundaki öğrencilerin görevi ise sınıf kütüphanesine bağış kitap toplamak, alınıp verilen kitapları kütüphane defterine kaydetmek ve kütüphanenin düzenini sağlamaktı. Spor kolundaki öğrenciler takımları kurmaktan sorumlu idi. En saygın ve ağır görev sınıf başkanlığı idi. Sınıf başkanı diğer kollarda olduğu gibi atama yöntemi ile değil seçim yolu ile belirlenirdi. Öğretmen kontrolünde gerçekleşen seçimde adaylar tahtaya çıkar, yüzlerini tahtaya döner ve seçim yapılırdı. En fazla oyu alan sınıf başkanı seçilirdi. Sınıf başkanı öğretmen gelmeden sınıf yoklama ve ders defterini müdür odasından alıp getirir, öğretmen gelene kadar sınıfın düzenini sağlar, konuşanları veya düzeni bozanları tahtaya yazardı. Adı tahtaya yazılan öğrenci gürültüye devam ederse adı tahtada kalır, susarsa adı tahtadan silinirdi. Öğretmen geldiğinde adı tahtada yazılı olan öğrenci çeşitli şekillerde hafif cezalara çarptırılırdı. En yaygın ceza 2-3 dakika tek ayak üzerinde durmak ya da teneffüste dışarı çıkma yasağ Tekkesarmaşık İlkokulunda bir öğrenciye verilebilecek en ağır ceza olduğundan öğrenciler öğretmen gelene kadar sessiz kalmaya dikkat ederlerdi.

Okulda hizmetli bulunmadığı zamanlarda okul bakım ve temizliği öğrenciler tarafından yapılırdı. Hizmetli istihdam edilemeyen yıllarda nöbetçi öğrenciler diğer öğrencilerden yarım saat erken okula giderek kış günleri sobaları yakar, yine aynı öğrenciler sınıfı süpürürdü. 1985 yılı itibariyle maaşı köy bütçesinden ödenmek kaydıyla 1 hizmetli istihdam edilmeye başlanmıştır. Hizmetliler genellikle köyün düşük gelirli kimseleri arasından seçilirdi. Fakat her öğretim yılında hizmetli istihdamı mümkün olmamıştır. Mesela 1985 yılında okulda bir hizmetli olduğu anlaşılmaktadır. 5 Kasım 1985 tarihli 20 nolu öğretmenler kurul kararın 10. maddesinden anlaşıldığına göre, mevcut hizmetlinin işini layıkıyla yerine getirmediği anlaşılmaktadır. Zira ilgili maddede, sınıf temizliklerine önem verilmesi ve "bu konuda okul hademesinin uyarılması ve çalışmaya sevk edilmesi” kararı yer almaktadır. Hizmetli uyarılara rağmen görevini yerine getirmemiş olmalı ki 23-24 Aralık 1985'te yapılan teftiş raporunda okulda hizmetli olmadığ kayıtlıdır. İlerleyen yıllarda da hizmetli problemi devam etmiştir. 1987-88 eğitim öğretim yılında maaşı köy bütçesinden verilmek üzere bir hizmetli mevcuttur. 23 Eylül 1988 tarihli 24 numaralı öğretmenler kurul kararın 1. maddesi de bu konu ile ilgilidir. İlgili karara göre, 30 Eylül 1988'de bir veli toplantısı yapılmasına ve "Hademe ve yakacak sorunun halledilmesine" karar verilmiştir. 
Yakacak temini de okulun en büyük problemi idi. Hatta zaman zaman her öğrenci okula gelirken 3-4 parça odun getirmek suretiyle yakacak odun temin edilerek ısıtma sağlanırdı. 20 ve 24 nolu kararlarda bu durum açıkça ifade edilmiştir. 4 Eylül 1989 tarihli 25 nolu kararın 11. maddesinde görüleceği gibi müstahdem ve yakacak temin işi köy bu tarihten sonra Okul Aile Birliği’nin uhdesine verilmiştir. Aynı husus 3 Eylül 1990 tarihli 27 nolu, 2 Eylül 1991 tarihli 29 nolu, 2 Eylül 1992 tarihli 29 nolu kararlarda tekrarlanmıştır. Ancak 1993 yılından itibaren müstahdem ve yakacak sorunu kalıcı olarak halledilmiştir. Zira 1993'ten sonra konuyla ilgili herhangi bir kayıt söz konusu değildir.

Okulun günlük giderlerine dair harcamalar da öğrencilerden para toplanılarak karşılanırdı. Tebeşir parası, fiş parası, karne parası, kitap parası, diploma parası okulun rutinleri arasındayd. Mesela 2 Ekim 1981 tarihli 12 nolu kararın 13. maddesinde yer alan, "Okul kitaplığına yeni kitaplar temin edilip öğrencilerin bundan en iyi şekilde yararlanmaları sağlanacak” şeklinde bir cümle vardır. Bu cümle bundan sonraki kurul kararlarının vazgeçilmezlerinden biri olacaktır. Kitaplar genellikle ya öğrencilerden doğrudan para ya da kitap toplamak sureti ile temin edilirdi.

\section{D-Ĕgitim Öğretim}

Okul tarihi boyunca hiçbir zaman 5 öğretmene sahip olmamıştır. Zaten 5 öğretmen olduğu takdirde eğitim verilebilecek sınıf da yoktur. Okulun maksimum kapasitesi 3 sınıftır. 1950-60 yıllarında 5 sınıf birleştirilmiş olarak öğretim görmüştür. Ardından okul kapanana kadar öğretmen sayısı 2-3 arasında değişmiştir. 1970'te 2, 1971'de 3, 1973-75 yllları arasinda 4, 1976-78'de 3, 1978-79 3, 197984 arasında 2, 1985-1996 arasında 3, 1997-2005 arasında ise 2 öğretmen vardır. Öğretmen ve derslik yetersizliğinde istenilen kalitede eğitim verilememiş olması aşikârdır. Bu açık öğretmenlerin gayret ve çabaları ile aşılmaya çalışılmıştır. Mesela 1973'te Cumhuriyet'in 50 Yılı Kutlamaları için alınan karar çok manidar ve anlamlıdır. Kararda, "50. Yila (Cumhuriyet Bayramı) elimizdeki imkânları seferber ederek gereği gibi kutlanmasına özel önem verilecek bu konuda görev taksimi yapılacaktır." ifadeleri yer almaktadır. Öğretmenler ellerindeki imkânların kıt olduğunun farkındadır. Ancak bunu bir tembellik vasıtası saymamış tam tersine var güçleri ile bu eksiklikleri gidermeye çalışmışlardır. Bu hususa özellikle değinmek gereklidir. Zira hemen hemen her kurul kararında Cumhuriyet Bayramı ve 23 Nisan Ulusal Egemenlik ve Çocuk Bayramı’nın özenli bir şekilde kutlanması yönünde kararlar vardır. Kutlamalar aynı zamanda köy-okul kaynaşmasına da vesile olan iki özel gündür. Bayramlarda okul bahçesinde yapılan kutlamalara genellikle tüm köy halkı katılır, öğrenciler tarafından gerçekleştirilen etkinlikleri izler; şiir, söylev, tiyatro ve monologları dinlerlerdi. Başarılı öğrenciler şiir ve monolog okuma işini üstlenirken, diğer öğrenciler kaşıkta yumurta taşıma, yoğurt kâsesi içinde bozuk para bulma, urgan çekme, koşu, ip atlama gibi bedensel etkinliklere katılır, böylece 
tüm öğrencilerin faaliyetlere katılması sağlanırdı.

Öğrencilerin gözünde temel ders olarak Türkçe ve Matematik dersleri kabul ediliyordu. Bu dersleri Hayat Bilgisi-Sosyal Bilgiler ve Fen Bilgisi izliyordu. Resim-İş, Beden Eğitimi ve Müzik dersleri ise öğrencilerin en sevdikleri ve eğlendikleri derslerdi.

Okulda Okutulan Dersler ${ }^{[26]}$

\begin{tabular}{|c|c|c|c|c|}
\hline 1. Sınıf & 2. Sınıf & 3. Sınıf & 4. Sınıf & 5. Sınıf \\
\hline Türkçe & Türkçe & Türkçe & Türkçe & Türkçe \\
\hline Hayat Bilgisi & Hayat Bilgisi & Hayat Bilgisi & Sosyal Bilgiler & Sosyal Bilgiler \\
\hline Matematik & Matematik & Matematik & Fen Bilgisi & Fen Bilgisi \\
\hline Resim-İş & Resim-İş & Resim-İş & Matematik & Matematik \\
\hline Müzik & Müzik & Müzik & $\begin{array}{c}\text { Din Kültürü ve } \\
\text { Ahlak Bilgisi }\end{array}$ & $\begin{array}{c}\text { Din Kültürü ve } \\
\text { Ahlak Bilgisi }\end{array}$ \\
\hline Beden Eğitimi & Beden Eğitimi & Beden Eğitimi & Resim-İş & Resim-I̧ş \\
\hline & & & Müzik & Müzik \\
\hline & & & Beden Eğitimi & Beden Eğitimi \\
\hline
\end{tabular}

Okulu bitirememek ya da okula devam edilmemesi köy okullarının en büyük problemlerinden biri olmuştur. Zira köyde altı yedi yaşından itibaren kız ya da erkek olsun tüm çocuklar bir şekilde üretime eklemlenmiştir ve onların çalışması için daima bir iş vardır. 10 yaşına gelmiş bir erkek çocuğunun kışın okula gelmeden önce ailenin hayvanlarının bakımını sağlaması ya da okul sonrası hayvan gütmeye gitmesi son derece olağan bir durumdur. Tekkesarmaşık köy halkı geçimini genellikle tütün ziraatı ile sağlamaktaydı. Tütünün hasada dönüşmesi çok emek isteyen ve uzun zaman dilimini kapsayan bir iştir. Süre bazen 1,5 yılı dahi bulabilmektedir. Büyükler tütün üretimi ile meşgul olurken, fazla emek istemeyen işler için çocuk emeğine gerek duyulurdu. Çocukların çalışması sadece okula devam problemine yol açmakla kalmaz, aynı zamanda ders çalışmaları için de büyük e gel teşkil ederdi. Bu yüzden öğretmenlerin çabasına rağmen okul akademik başarısı her dönem istenilen seviyede seyretmemiştir. Çocukların ya da ailenin samimi çaba ve ısrarı yoksa 1980 öncesinde öğrencilerin ortaöğretim ya da yüksek eğitime geçişleri yok denecek kadar az olmuştur. Buna rağmen bazı istisnaî örnekler de yok değildir. Mesela 1958'de okula başlayıp mezun olan dönemin öğretmeni Osman Demirbaş’ın oğlu İbrahim Demirbaş Fen Bilgisi öğretmeni olmuş ve 1983’ten itibaren İkizpınar Ortaokulu müdürü olarak görev yapmıştır. Bir başka örnek ise sınıf öğretmeni olup Tekkesarmaşı İlkokulunda 19 yıl görev yapan Hüseyin Du-

26 Resim 6-7.

27 1982-83 Eğitim Öğretim yılına kadar bu ders Ahlak Bilgisi ve Din Dersi olarak iki ayrı dersten oluşmaktaydı. 
man'dır. Bu örneklere ilave olarak Eğitim Enstitüsü bitiren Mevlut Er, İsmail Aydın ve Niyazi Ak 1960'larda okuldan mezun olup üniversite bitiren diğer kişilerdir. Akademik başarı okul tarihi boyunca problem olmuştur. Mesela 25 Kasım 1982 tarihli teftişte 14 kişilik 2. sınıf öğrencilerinden 3 öğrencinin, 16 kişilik 3. sınıf öğrencilerinden 3'ünün okuma yazmasının zayıf olduğu tespit edilmiştir. 10 Ocak 1985 tarihli teftişte 4. sinıfta 4, 5. sinıfta 2 öğrenci hâlâ Türkçe yazma ve okuma konusunda sıkıntılı olup, 7 öğrencinin ise yazısı okunamayacak kadar kötüdür. 24 Aralık 1985 teftişine göre, 19 öğrenci bulunan 3. sinıf öğrencilerinden 10’unun defter kullanmada sorunları, 4 öğrencinin 1. sınıf seviyesinde olduğu, 6 öğrencinin ses eksikliği tespit edilmiş sınıfta sadece 6 öğrenci normal seviyede bulunmuştur. $\mathrm{Bu}$ konuda teftiş raporlarında onlarca başka örnek daha vardır. Problem ilerleyen yıllarda da devam etmiştir. Buna karşın öğretmenler sürekli olarak akademik başarıyı artıracak yöntemler üzerinde kafa yormuş, öğretmenler kurul karar defterindeki kayıtlara göre bu konu ile ilgili onlarca tedbir alınarak hayata geçirilmiştir. ${ }^{[28]}$

Mevcut problemlere rağmen 1980 sonrasında daha ileri eğitim kurumlarına devam eden öğrenci sayısında artış yaşanmıştır. Özellikle 1990'larla birlikte üniversitede kazanan ve mezun olan öğrenci sayısında da belirgin bir artış vardır. $\mathrm{Bu}$ yıllarda Tekkesarmaşık İlkokulu öğrencilerinin genel akademik başarısı çevre köy okullarından ileri düzeydedir. Bugün o tarihlerde mezun olan öğrenciler öğretmen, polis, mühendis olarak birçok iş kolunda görev almış durumdadırlar. ${ }^{[29]}$

\section{E-Araç-Gereç}

Resmi olarak kamuya ait bir kurumdaki araç gereçler demirbaş eşya listelerinden anlaşılmaktadır. Okulun en eski demirbaş kaydı olan 1 Kasım 1965 tarihli kayda göre, okulda 32 öğrenci sırası, 1 yazı tahtası, masa, termometre, masa saati vardır. Bunun yanında tıraş makinesi, süt kazanı, süt kaynatma sobası, süt kepçesi, süt süzeği gibi beslenmeye yönelik araç gereçler dikkat çekmektedir. Ders malzemelerine gelince, 1 dünya küresi, bezli Türkiye haritası, bezsiz Türkiye haritası, Dünya, Asya, Avrupa, Afrika, Kuzey ve Güney Amerika, Okyanusya haritaları mevcuttur. Bunun yanında 5 adet tabiat levhası, 4 adet tarihi hükümdarlar, 2 adet büyük Türk şairleri resmi, T cetveli, gürgen gönye ve pergel, keser, yangın cetveli, kürek, testere, zil, masa, sandalye, yazı takımı, soba, bayrak, su kuyusu ipi diğer malzemelerdir. Bu kayıtlardan okulda Atatürk resmi olmadığı anlaşılmaktadır. Yine sütle ilgili malzemeler dikkate alındığında Marshall Planı sonrası tüm yurtta dağıtılan süt tozu furyasından Tekkesarmaşık İlkokulunun da nasibini aldığı anlaşılmaktadır. O tarihlerde okulda öğrenim gören öğrenciler de içtikleri sütün süt tozundan imal edildiğini teyit etmektedirler. Hatta büyük veya küçükbaş hayvanı olmayan ailelere

28 Tekkesarmaşık Köyü Ilkokulu Öğretmenler Teftiş Rapor Klasörü.

29 Şahsî bilgilerim ve okulun müdürlerinden müteveffa Hüseyin Duman’la 2021 Nisan ayında yapılan mülakat. 
de süt tozu dağıtımı yapılmıştır. Okul kütüphanesinde 73 adet kitap bulunmaktaydı. Bunlardan İstatistik Kılavuzu, Nutuk, Kuran-ı Kerim'den Ayetler, Siğırların Bulaşıcı Hastalıkları, Hububatın Başlıca Düşmanları, Sıtma, Yurdumuz Nasıl Bir Yerdir, Köyde İçme Kullanma Suyu, Süt ve Süt Sağlı̆̆ı, Gebelerin Bakımı, Çocuğumuzu Hastalıklardan Nasıl Koruruz, İshalden Korunalım, Hayvan Hastalıklarından Korunma, Sitma Savaşı, Meyve ve Sebze Kurutma, Altın Yaprak Memleketi Bafra gibi kitaplar dikkati çekmektedir. Bu kitapların okul kütüphanesinde mevcudiyeti düşünüldüğünde okulda verilen eğitimin sadece bilgi vermekle sınırlı olmadığı, köy çocuklarını karşılaşabilecekleri problemlere karşı da hazırlamak olduğu ortaya çıkar. Bunların haricinde diğer kitaplar günümüzde 100 temel eser olarak bilinen, Pinokyo, Altın Bülbül, Heidi, İki Sene Mektep Tatili, La Fontain'den Masallar gibi okuma kitaplarıdır. 1967'de demirbaş listesine Atatürk Büstü, 2 adet Atatürk resmi ve 1 adet İstiklal Marşı eklenmiştir. 1967'de eklenen diğer malzemeler ecza dolabı ve pusula olmuştur.

Demirbaş defterinden elde edilen kayıtlara göre, 1980 Askeri Darbesi'nden sonra okulda yeni bir düzenlemeye gidilmiştir. Darbenin getirdiği sert iklimde s1nıflar ve okul MEB mevzuatına göre yeniden düzenlenmiştir. Evvela bir yangın köşesi oluşturulmuş, ardından her sınıfa Atatürk Portresi, Atatürk'ün Gençliğe Hitabesi ve İstiklâl Marşları standart olarak dâhil edilmiştir. Atatürk Portreleri daha evvel mevcut iken Atatürk'ün Gençliğe Hitabesi ve İstiklâl Marşlarının temini gerekmiştir. Bu amaçla tanesi 1.200 TL'den 4 adet İstiklâl Marşı ve tanesi 1.200 TL'den 4 adet Atatürk'ün Gençliğe Hitabesi satın alınmıştır. Yine 6.950 TL masrafla bir Yangın Köşesi hazırlanmıştır. Tüm bu alımların masrafları köy bütçesinden karşılanmıştır. 1983'e gelindiğinde okulun araç gereç ihtiyacı büyük oranda tamamlanmıştır. Sosyal Bilgiler ve Fen Bilgisi ders setleri, mevsim şeritleri, çerçeveli Atatürk, İstiklâl Marşı, Andımız, İl ve İlçe Haritaları, 50. Yıl Marşı her sınıfta yerini almıştır. 19 Şubat 1984’te okulda 23 öğrenci sırası bulunurken, 17 Nisan 1984’te Milli Eğitim Müdürlüğünden 5 sıra daha temin edilerek okula kazandırılmıştır. ${ }^{[30]}$

2002 yılında ilköğretim kaynaklarının daha verimli kullanılarak eğitim kalitesinin artırılmasına ve birlikte işbirliği yapma bilincini geliştirmek maksadıyla Kardeş Okul uygulamasına geçilmiştir. Kardeş okul projesinden beklenen fayda okulların ders araç-gereç ve donatım malzemesine ilişkin gereksinimlerinin karşılanmasına yardımcı olmaktı. Bu uygulama 25 Mart 2002 tarihinde Bafra İlçesi'nde de hayata geçilmiştir. Tekkesarmaşık İlköğretim Okulu, komşu köy okulu olan İkizpınar Aliefendi İlköğretim Okulu ile kardeş okul olmuştur. Anlaşılacağı gibi, zaten donanım açısından yetersiz olan bir okulun başka bir köy okulu ile kardeş okul yapılmasından bir fayda elde edilememiştir. 


\section{SONUÇ}

Tekkesarmaşık Köyü İlkokulu 10 Kasım 1950'de tek sınıflı, tek öğretmenli bir okul olarak eğitime başlamıştır. 2006 yılına kadar eğitim kesintisiz devam etmiştir. Okul ilk açıldığında köylünün tek beklentisi çocuklarının okuma yazma ve dört işlem yapabilecek kadar matematik öğrenmesidir. Bundan dolayı ilk yıllarda çoğu öğrenci ikinci sınıftan sonra okula devam etmemiştir. 1980’lere kadar durum pek de değişmemiş, sınıf tekrarları veya mezun olmadan okuldan ayrılmak rutin bir hal almıştır. Okulda yaşanan bir diğer problem ise istikrarsız öğrenci ve öğretmen sayılarıdır. Köy nüfusundaki azalmaya paralel olarak gittikçe azalan sayıda öğrenci kaydolan okulda doğal olarak öğretmen sayısı da azalmıştır. Öğretmen yetersizliği eğitimi de etkilemiş, iki ya da üç öğretmen olduğu dönemlerde tüm öğrenciler yeterli eğitimi alamamıştır. Tekkesarmaşık Köyü İlkokulu öğretmenleri halkının orta gelirli bir bölgede olmasının sıkıntısını çekmiş, okuldaki eksikler devlet tarafından karşılanamadığı zaman problemler sürekli ertelenmiştir. Zamanla eskiyen binada ciddi yıpranmalar meydana gelmiş ancak bu eksikler bir türlü giderilememiştir. Tuvalet temizliği, hizmetli yokluğu, öğretim araç gereç eksikliği daima yaşanan durumlardır. Tüm bu eksikliklere rağmen kurulduğu günden kapandığı güne kadar köyün kalbi, çocukların neşesi olmaya devam etmiştir. Özellikle resmî bayramlarda yapılan törenler köy halkının heyecanla izlediği etkinlikler olmuş, okul millet kaynaşması sağlanmıştır. Okul yarım asır boyunca köyde yetişen yüzlerce çocuğun en güzel anılarını süsleyen yer olmuştur. Bu sebeple Kültür ve Milli Eğitim Bakanlıkları bir proje geliştirerek kapanmış köy okulları Etnografya Müzeleri’ne dönüştürülmelidir. Gerekli malzeme yöre halkından gönüllük usulüne göre toplanmalı ve okullarda koruma altına alınmalıdır. Böylelikle hem kültürel aktarım sağlanmış, hem köy hafızası diri tutulmuş hem de yöre halkının okullarına sahip çıkmaları teşvik edilmiş olacaktır.

\section{KAYNAKLAR}

1990 Genel Nüfus Sayımı. Nüfusun Sosyal ve Ekonomik Nitelikleri 20.10.1985. Ili:55-Samsun, TC. Başbakanlık Devlet İstatistik Enstitüsü, Ankara 1994.

AKYÜZ, Yahya; Türk Eğitim Tarihi, Pegem Akademi, Ankara 2010.

Genel Nüfus Sayımı Nüfusun Sosyal ve Ekonomik Nitelikleri 12.10.1980. Ili:55-Samsun, Başbakanlık Devlet İstatistik Enstitüsü, Ankara 1983.

Genel Nüfus Sayımı Nüfusun Sosyal ve Ekonomik Nitelikleri 20.10.1985. Ili:55-Samsun, Başbakanlık Devlet Istatistik Enstitüsü, Ankara 1989.

Resmi Gazete, 18 Ağustos 1997, Sayl: 23084.

Milli Eğitim Bakanlığı Ilköğretim Genel Müdürlüğü, Ilköğretim Genel Müdürlüğüne Bağlı Şehir, Kasaba, Köy Ilkokulları ve Bu Okullara Ait Bazı Bilgiler, Milli Eğitim Basımevi, Istanbul 1966.

Tekkesarmaşık Köyü Ilkokulu Demirbaş Eşya Defteri.

Tekkesarmaşık Köyü Ilkokulu Karar Defteri.

Tekkesarmaşık Köyü Ilkokulu Okul Kütüğü, I.

Tekkesarmaşık Köyü ilkokulu Öğretmenler Izin Defteri.

Tekkesarmaşık Köyü Ilkokulu Öğretmenler sicil Defteri. 
Tekkesarmaşık Köyü Ilkokulu Öğretmenler Teftiş Rapor Klasörü.

Türkiye Cumhuriyeti Başbakanlık Istatistik Genel Direktörlüğü, Genel Nüfus Sayımı Kat’î ve Mufassal Neticeler Samsun Vilâyeti, Mehmet ihsan Basımevi, Ankara 1937.

的筑

\section{RESIMLER}

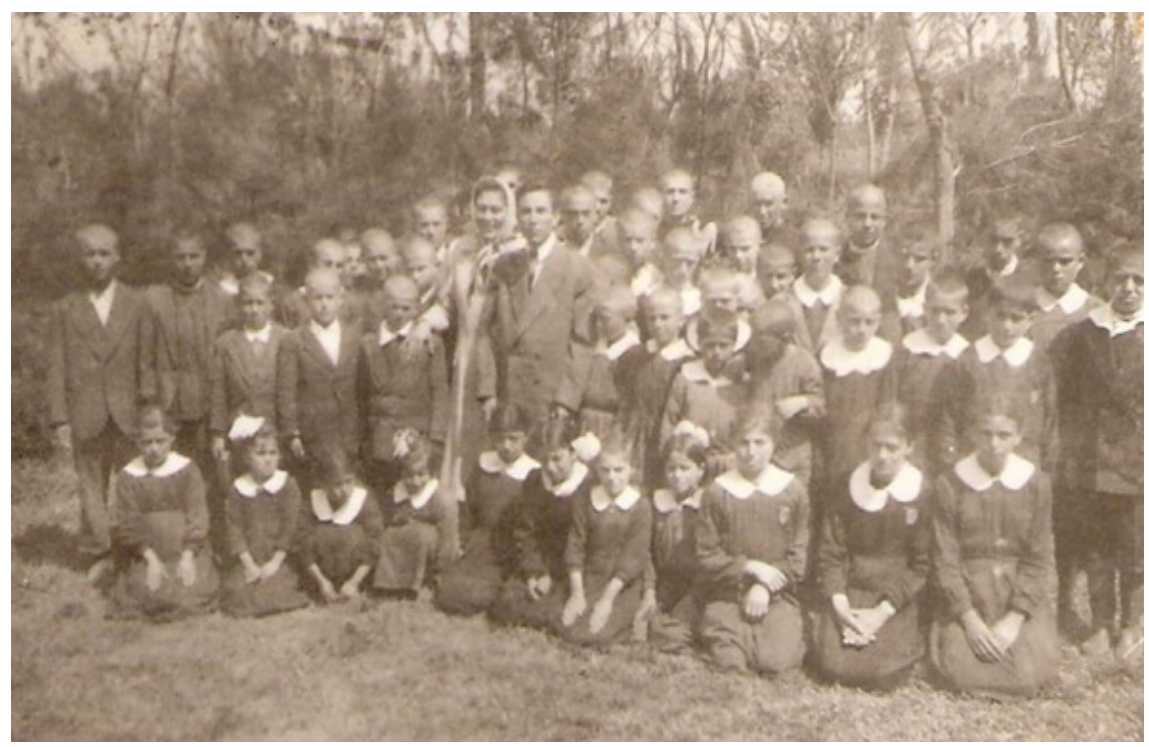

Resim 1: Hüseyin Ataklı ve 1950 kayıtlı öğrenciler 1951-52 senesi Mayıs ayı (Z. Gölen özel arşivi). 


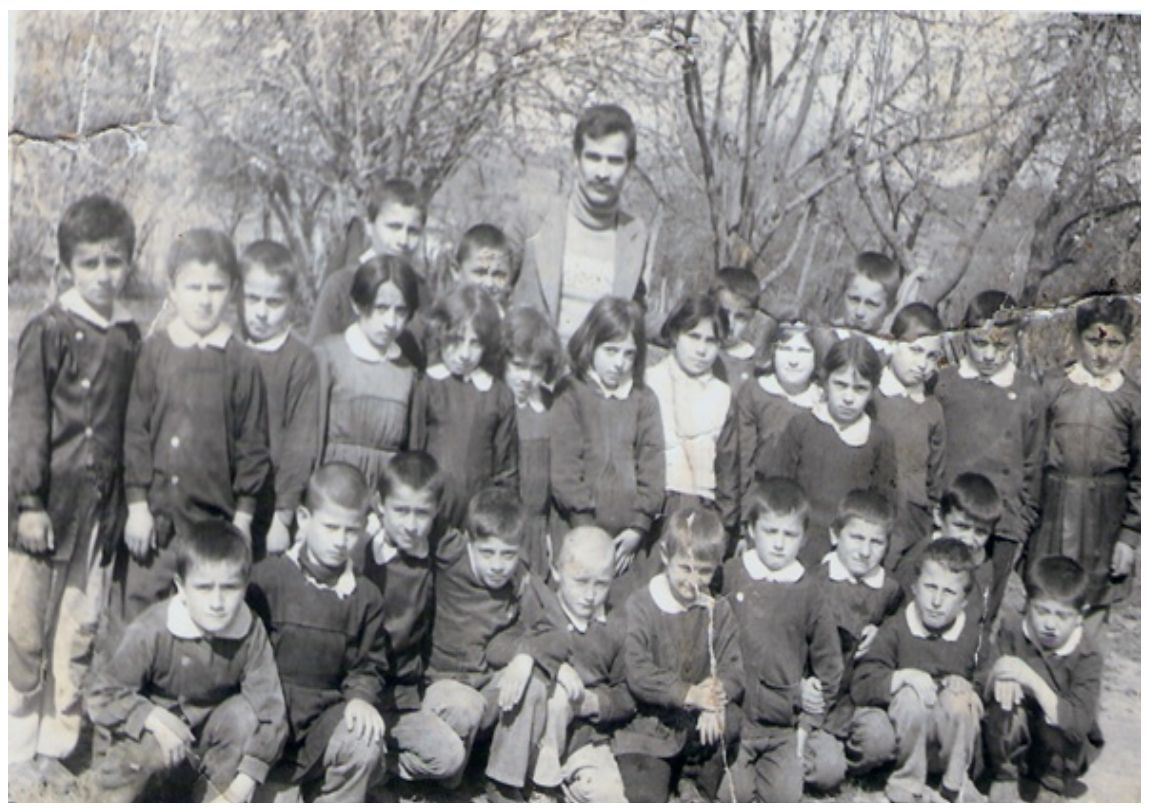

Resim 2: Erol Tokur öğrencileri ile 1979-80 Eğitim Öğretim Yılı Bahar ayları (Z. Gölen özel arşivi).

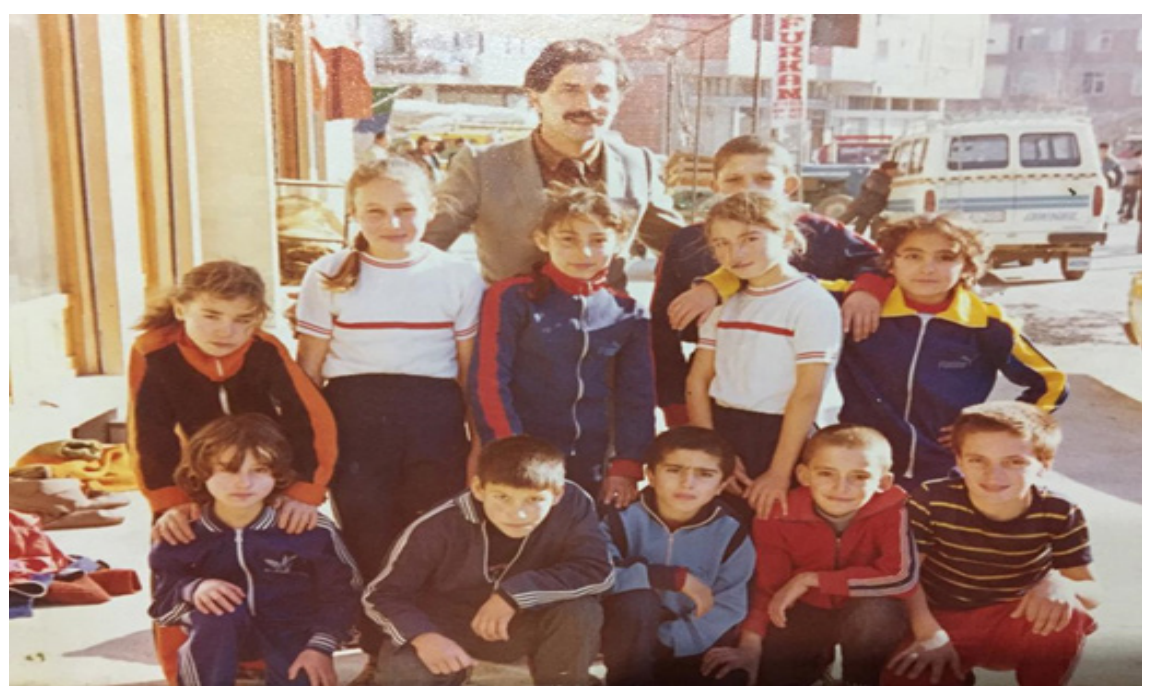

Resim 3: Kamil Sarı Bafra Atatürk Koșusunda Tekkesarmaşık İlkokulu Takımı ile. Nisan 1985 (Z. Gölen özel arșivi). 


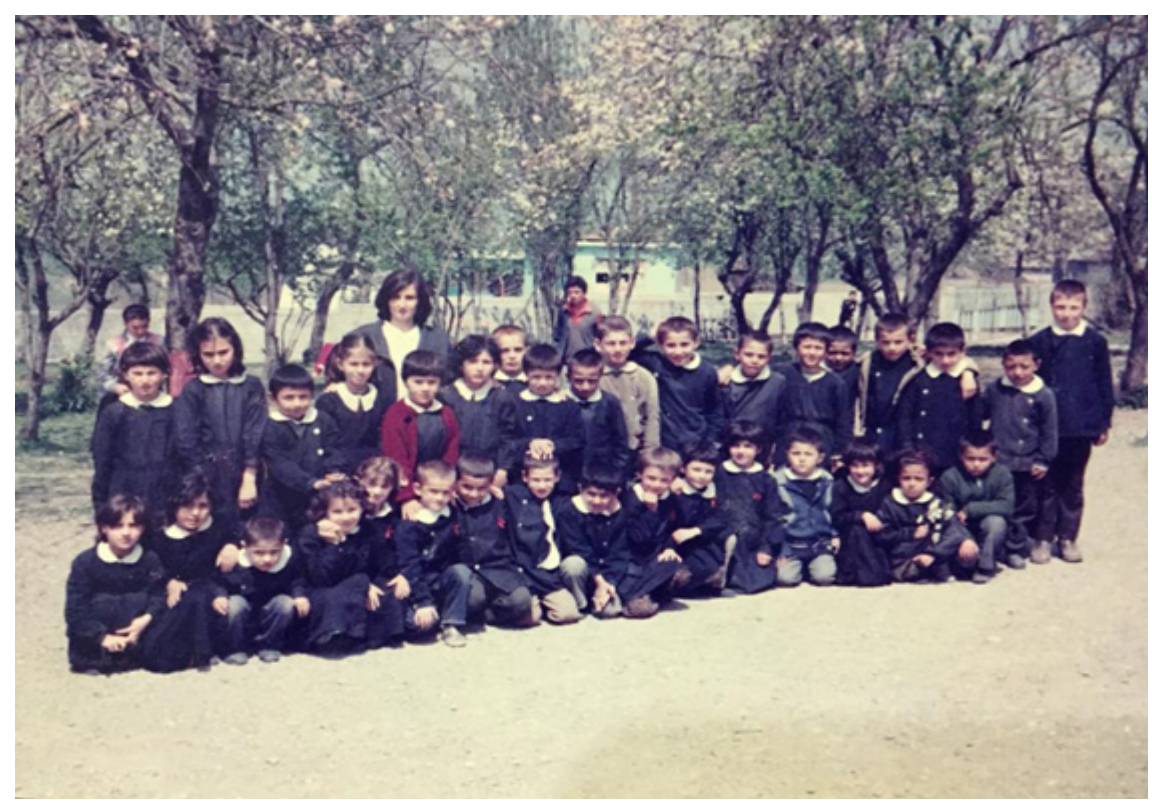

Resim 4: Devrim Doğanay öğrencileri ile 1985-86 Eğitim Öğretim Yılı Bahar ayları (Z. Gölen özel arşivi).

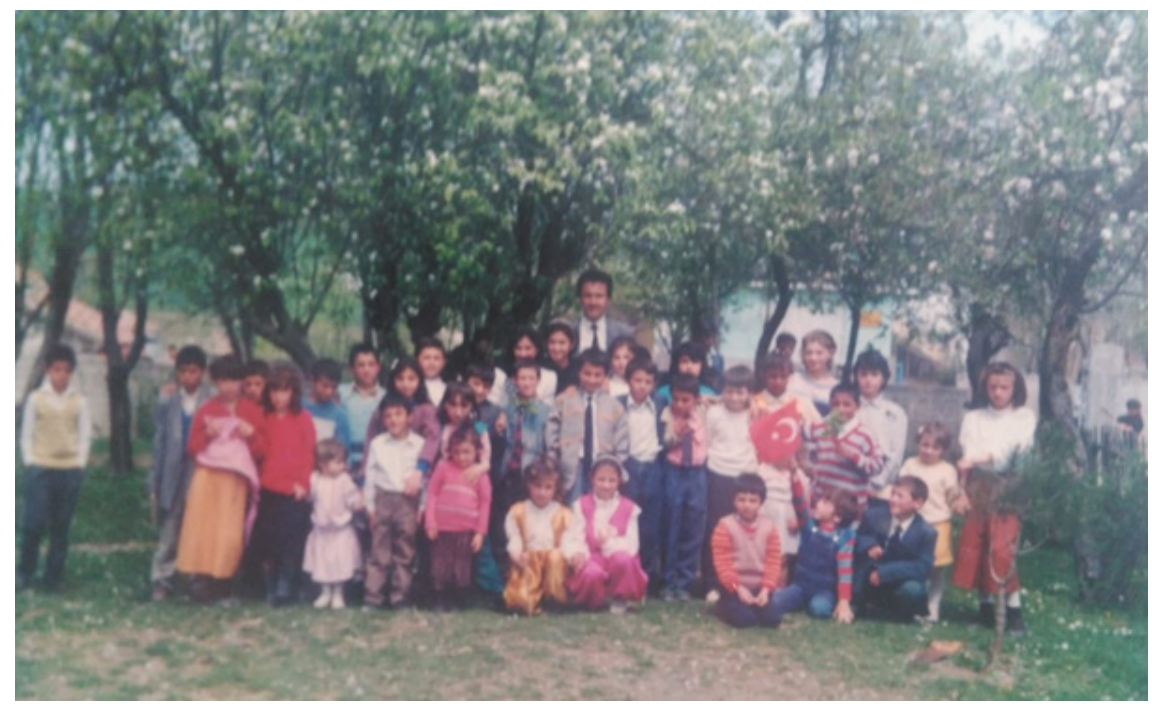

Resim 5: Hüseyin Duman ve öğrencileri okul uygulama bahçesi önünde (23 Nisan 1991) (H. Duman özel arşivi) 

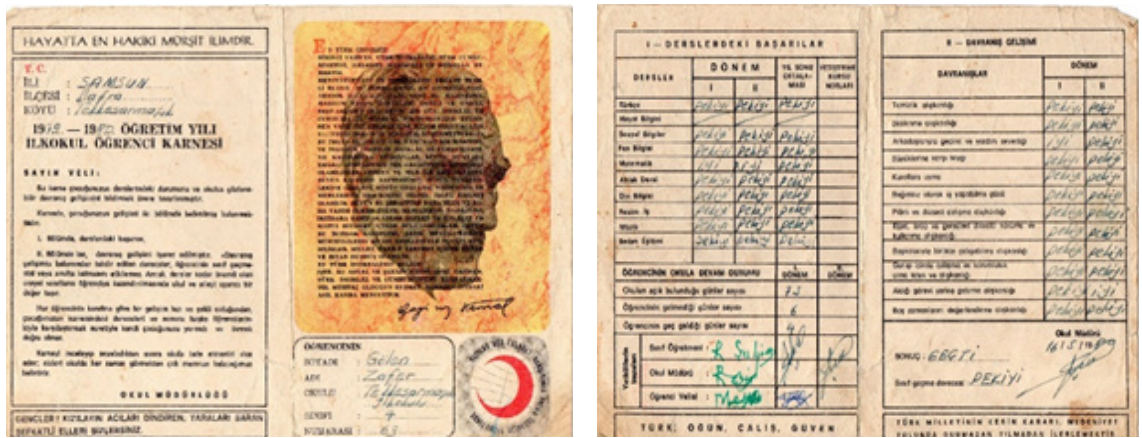

Resim 6: Tekkesarmaşık İlkokulu Tarafından Verilen Bir Karne (16 Mayıs 1980) (Z. Gölen özel arşivi).
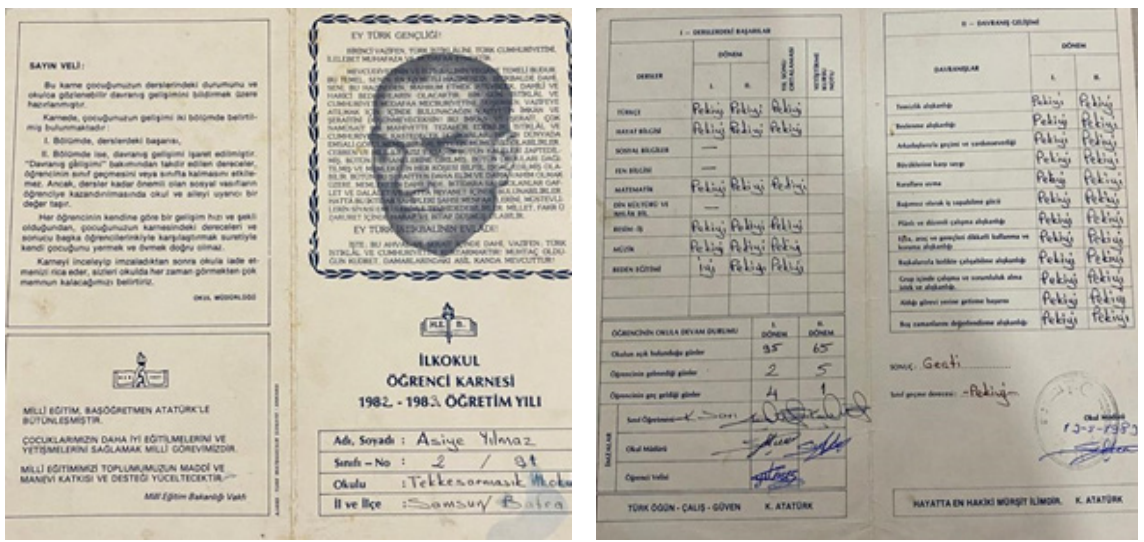

Resim 7: Tekkesarmaşık İlkokulu Tarafından Verilen Yeni Tip Bir Karne (13 Mayıs 1986) (Z. Gölen özel arşivi).

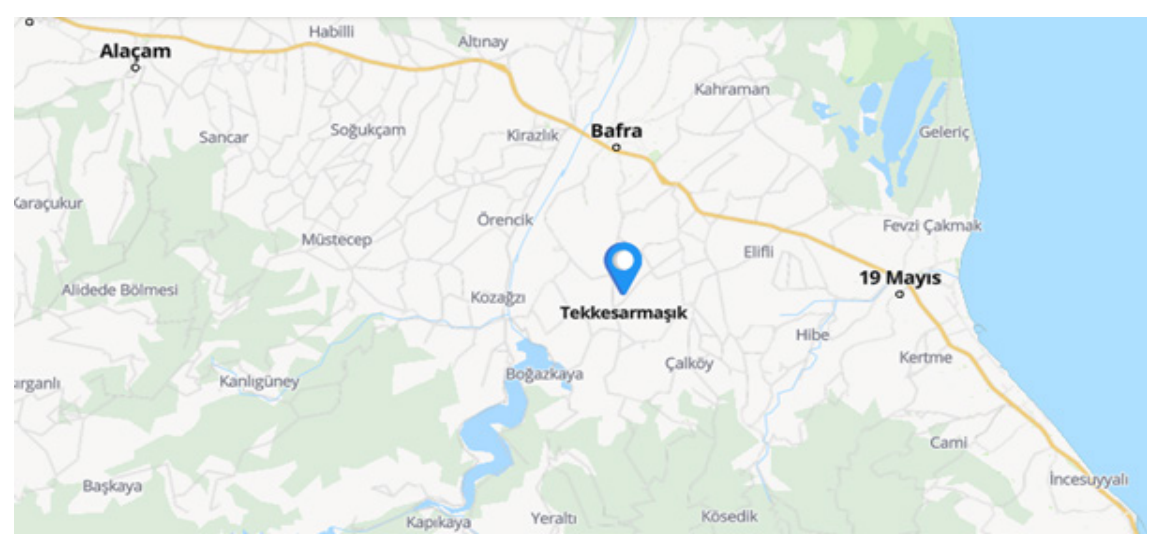

Resim 8: Tekkesarmaşık Köyü (Mahallesi). Kaynak: https://atlas.harita.gov.tr/\#5/39/3,

(Erişim Tarihi: 09.03.2021) 


\begin{tabular}{|l|l|}
\hline$\vdots$ & Öznitelik Bilgisi \\
\hline Taşınmaz No & 107298750 \\
\hline il & Samsun \\
\hline İlçe & Bafra \\
\hline Mahalle/Köy & ikizpinar \\
\hline Ada & 149 \\
\hline Parsel & 1 \\
\hline Tapu Alanı & $3.180,01$ \\
\hline Nitelik & $\begin{array}{l}\text { Kargir okul ve uygulama } \\
\text { bahçe }\end{array}$ \\
\hline Mevkil & Memoğlu \\
\hline Zemin Tip & Ana Tașinmaz \\
\hline Pafta & F35-b-04-a-4 \\
\hline
\end{tabular}

Resim 9: Okula Ait Taşınmaz Kayıt Bilgileri

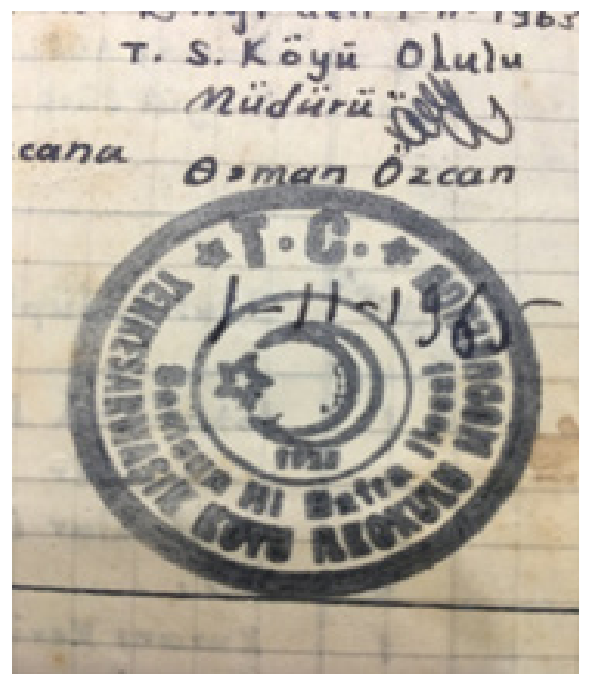

Resim 10: Okulun İlk Mührü.

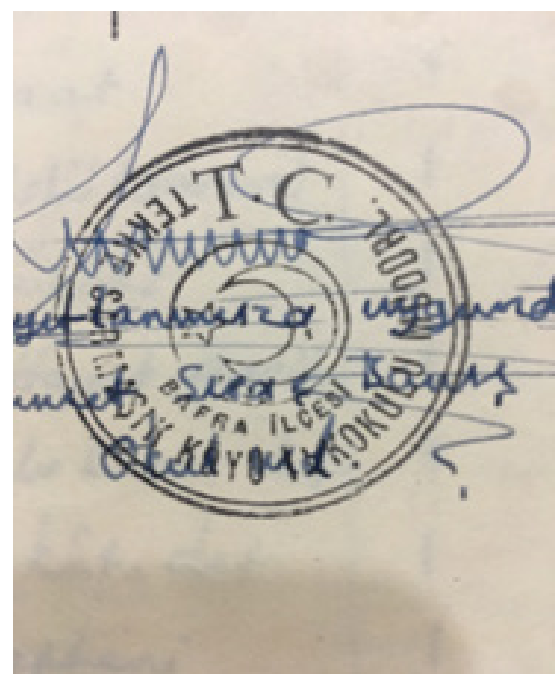

Resim 11: Okulun İkinci Mührü. 


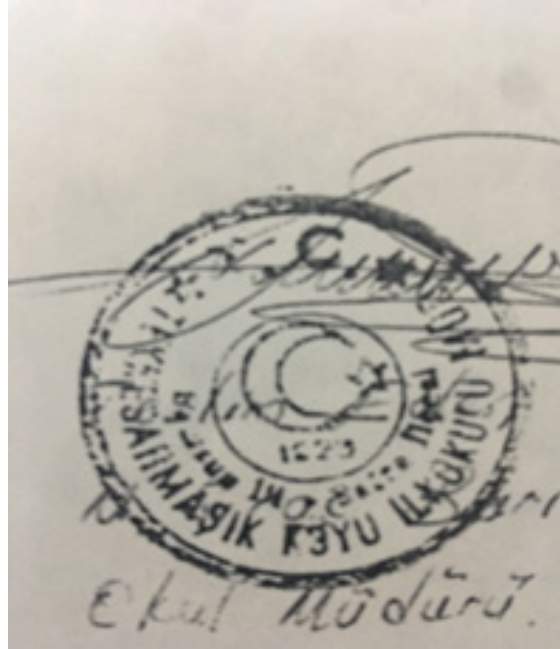

Resim 12: Okulun Üçüncü Mührü (1984-1998)

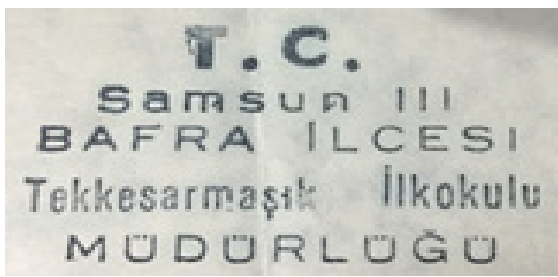

Resim 14: Okulun İlkokul İken Kullanılan Kaşesi

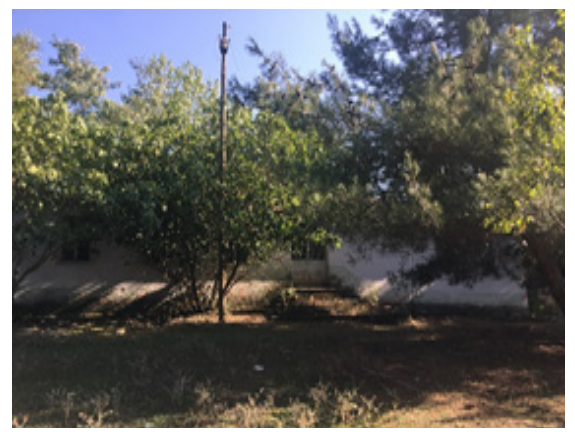

Resim 16: Okulun Günümüzdeki Hali

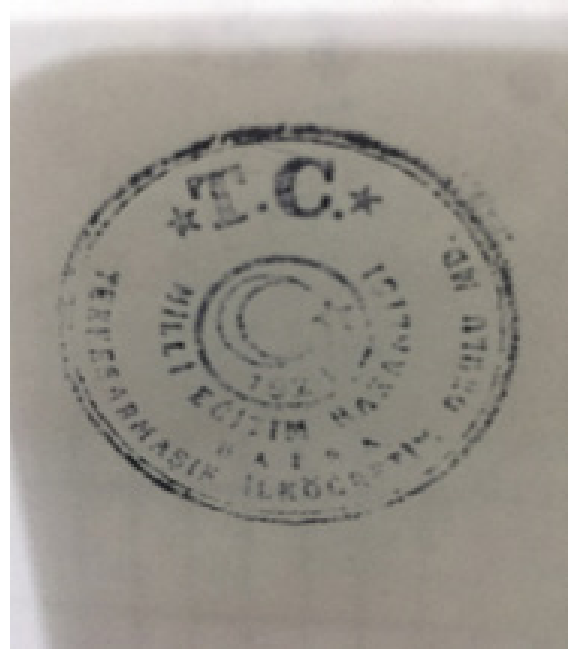

Resim 13: Okulun Son Mührü (1998-2006)

\section{SAMSUN - BAFRA}

Tekkesszmaşik flköğretim Ukulu

Müdürlüğü

Resim 15: Okul İlköğretim Okuluna Çevrildikten Sonraki Kaşesi

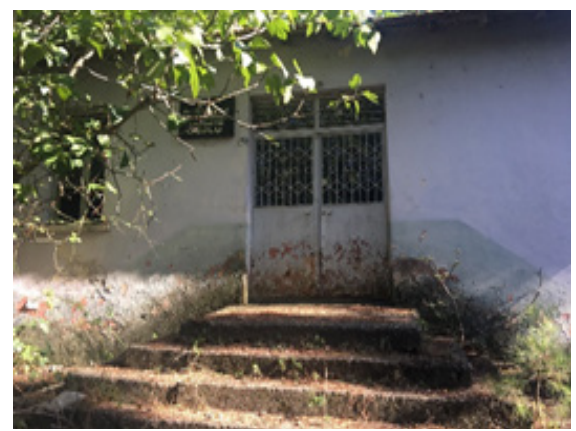

Resim 17: Okulun Giriş Kapısı 


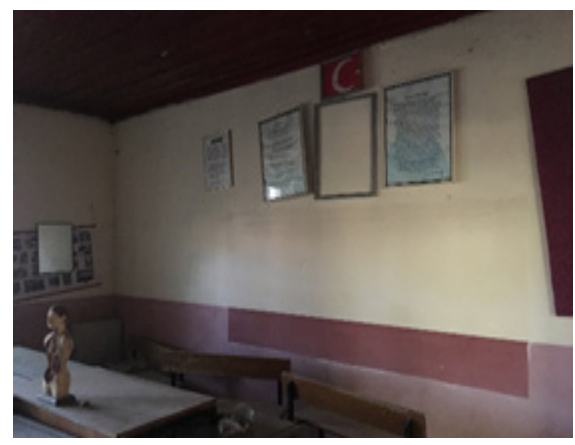

Resim 18: Sinıf

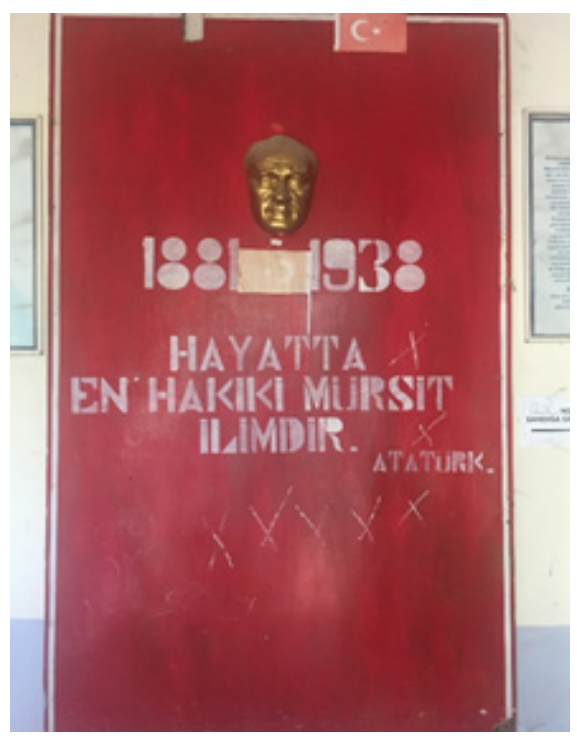

Resim 20: Giriș Salonu

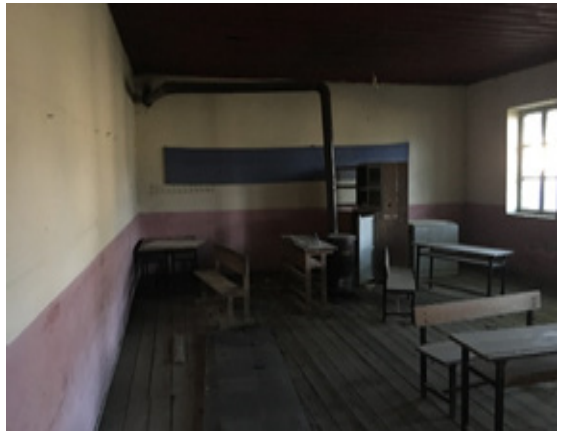

Resim 19: Sinıf

\section{ANDIMIZ}

Türk'üm, doğruyzum, çalışkanum. İkem, küçüklerimi korumak, büyüklerimi sajmak, yurdumu, milletimi özümden çok sermektir. Ūiküm yükselmek, ileri gitmektir.

Ey büyük Atatürk! Açtığın yolda, gösterdiğin hedefe durmadan yürüyeceğime ant içerim. Varlğğm, Türk varhğına armağan olsun.

¿Ne mutlu Türküm diyene,

Resim 21: Andımız 


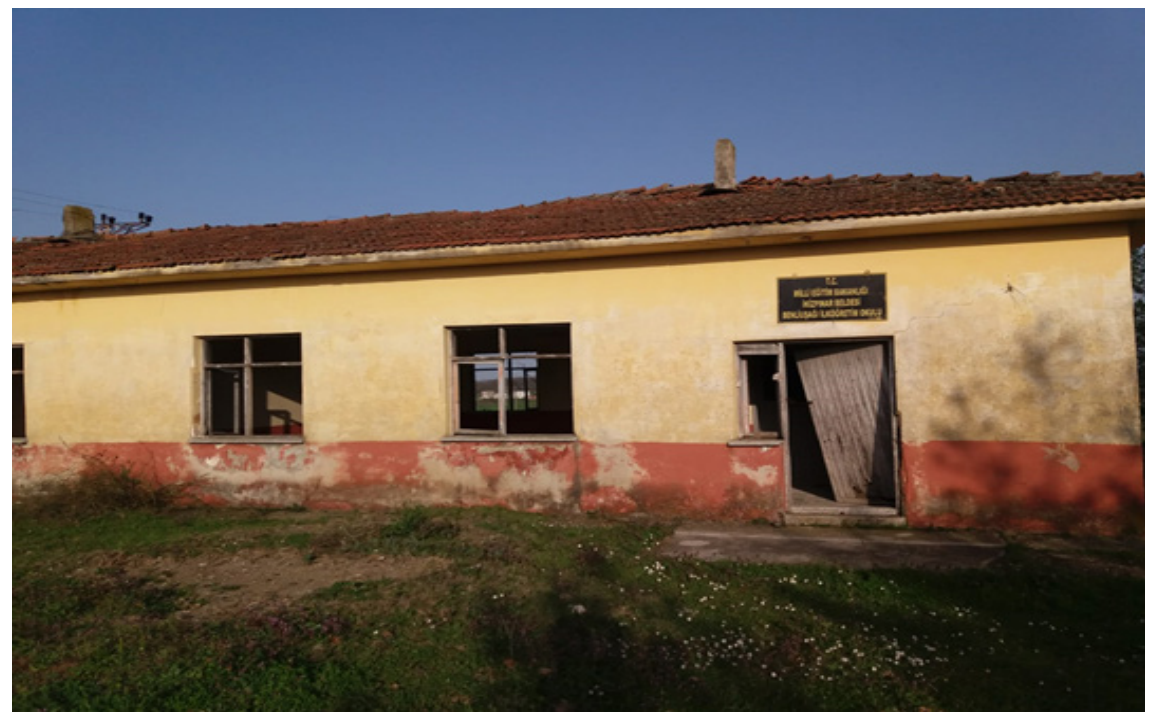

Resim 22: Benliuşağı İlköğretim Okulu

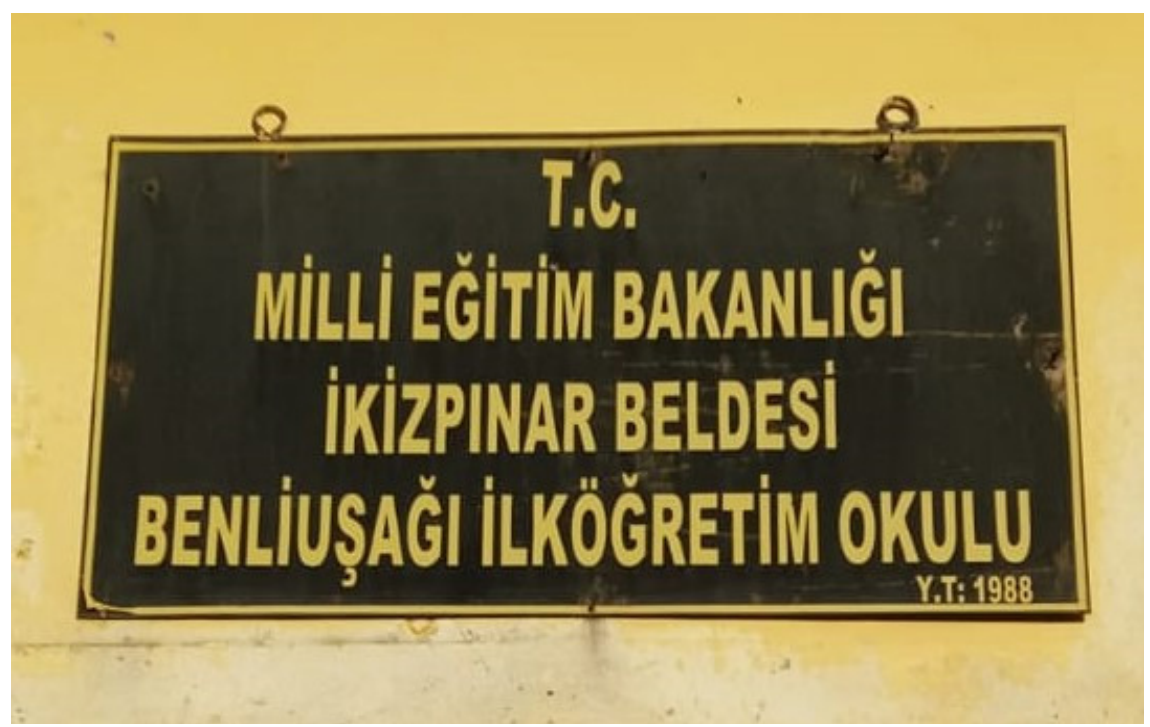

Resim 23: Benliuşağı İlköğretim Okulu Tabelası 


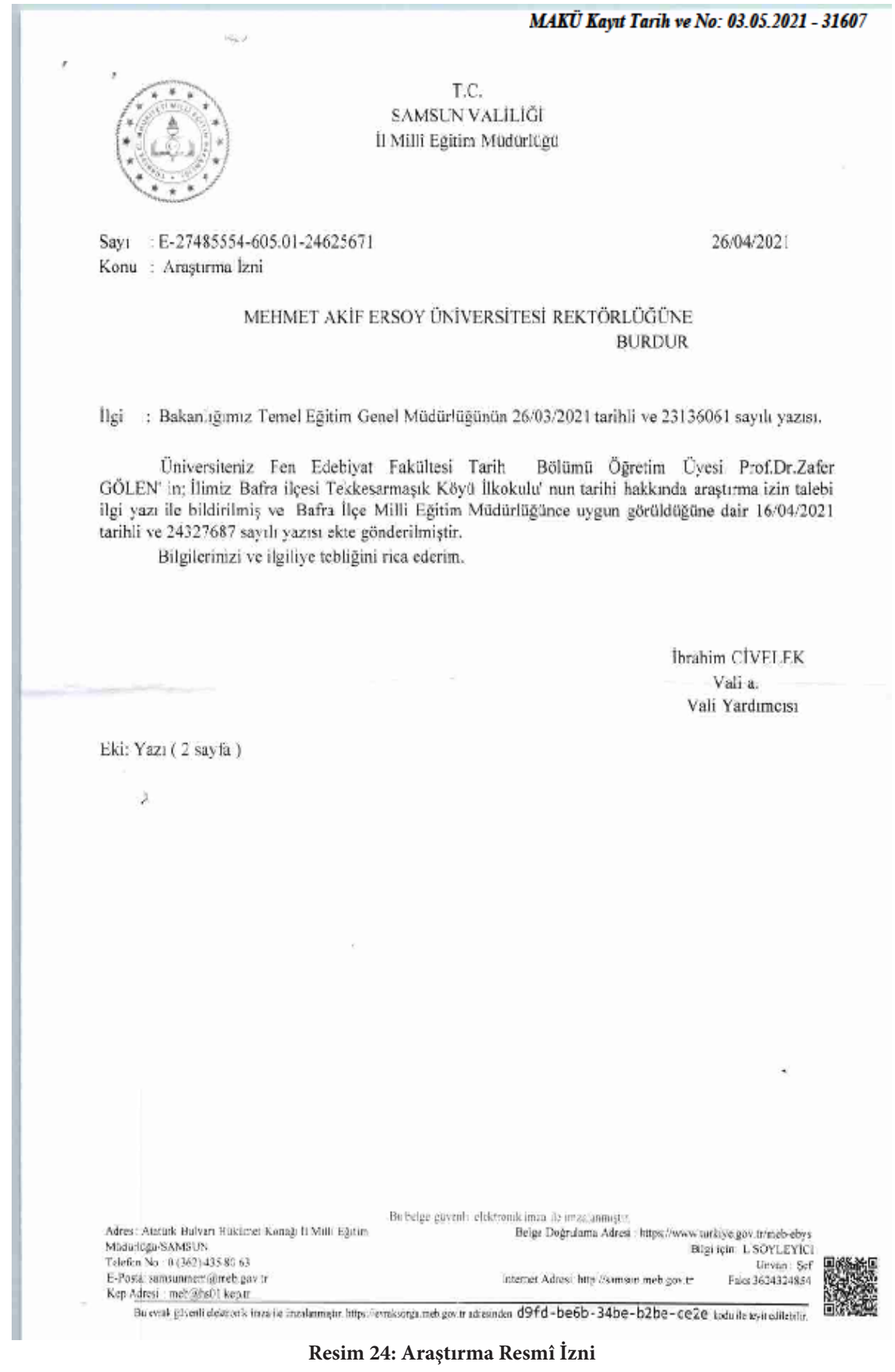

